\title{
Projeções Ortogonais
}

Trabalho de Conclusão de Curso

Coordenação Central de Educação a Distância PÓS-GRADUAÇÃO LATO-SENSU Tecnologias no Ensino Superior 


\section{Projeções Ortogonais}

Trabalho de conclusão de curso apresentado à Coordenação do Curso de Especialização Tecnologias no Ensino Superior como requisito parcial para obtenção de título de Especialista em Tecnologias no Ensino Superior.

Orientador

Prof.Ph.D. Marcelo Dreux

Coordenação Central de Educação a Distância Curso de Especialização Tecnologias no Ensino Superior 


\section{ÍNDICE}

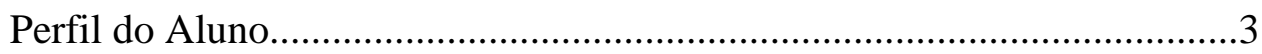

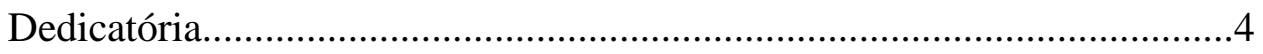

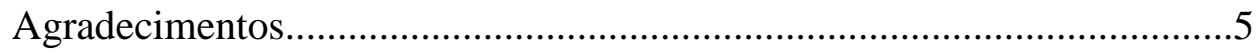

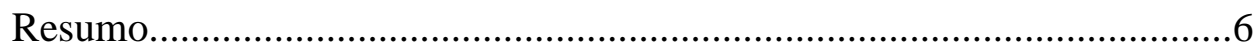

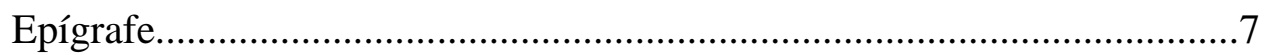

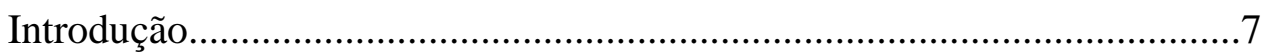

Capítulo 1 - Fundamentação teórica: Geometria Descritiva.........................11

Capítulo 2 - Projeções Ortogonais............................................................15

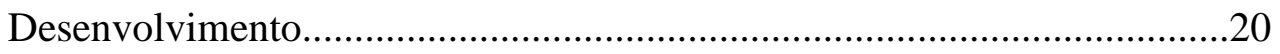

Capítulo 3 - Percepção Visual.......................................................................27

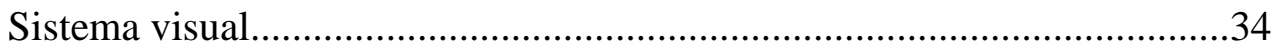

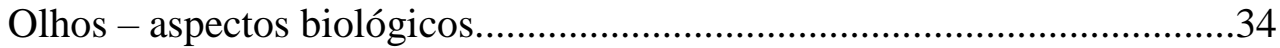

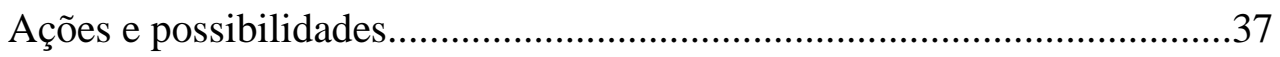

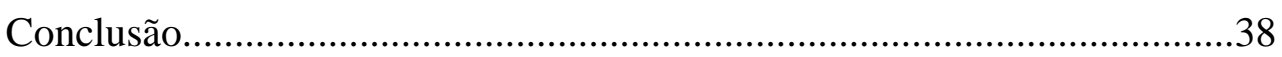

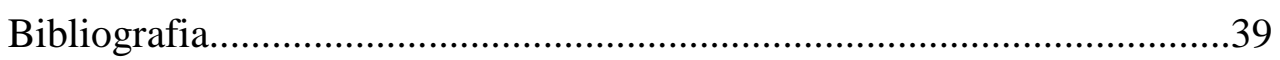

\section{Índice das figuras}

As figuras sem referência de autoria do autor.

- Figura 1, Leonardo da Vinci, máquina para erguer e transportar materiais escavados em um canal......................................................

- Figura 2, Desenho esquemático com os diferentes elementos do sistema de transmissão. Obtido em 14 de fevereiro de 2016 em: http://www.prof2000.pt/users/hjco/azeite/Cap03_066.htm................8

- Figura $2^{\mathrm{a}}$, Esquema de um moinho de fubá caipira em casinha de taipa de mão e a nomenclatura mais usada no Vale do Paraíba, em São Paulo. Desenho Francisco Andrade.

- Figura 3, Desenho de uma máquina de turfa movida à vapor do início do século XX.

- Figura 4, Desenho para patente de Automóvel para H. W. Libbey Automobile Vehicle de 04 de setembro de 1900. 
- Figura 5, publicado em dezembro de 2013: For more Engineering Drawing solutions, http://geniusnepal.com/.................................10

- Figura 6, The requirements of machine drawings (Manufacturing Drawings), em: http://www.jensen-consulting.co.uk/blog/therequirements-of-machine-drawings-manufacturing-drawings.........10 
Todos os direitos reservados. É proibida a reprodução total ou parcial do trabalho sem autorização do autor, do orientador e da universidade.

\section{Perfil do aluno}

Ronaldo Rodrigues Bastos

Graduado em Design, com ênfase em Projeto de Produto (PUC-Rio), pósgraduado em Docência do Ensino Fundamental e Médio com ênfase em Desenho (Universidade Cândido Mendes). Lecionou Desenho Técnico na Escola Naval, no Rio de Janeiro. Atualmente é professor de Desenho Técnico I e II no Curso de Engenharia da PUC-Rio. 


\section{Dedicatória}

Dedico este trabalho aos professores de Desenho Técnico, obstinados em fazer seus alunos enxergarem as peças que veem. Que ousam transitar entre a matemática e a arte, a geometria plana e a natureza, reduzindo ao traço de uma reta a mais complexa forma observada. 


\section{Agradecimentos}

Ao meu pai, amigo e professor, Nilson Bastos Monteiro que, com seus 37 anos de dedicação ao Magistério, foi exemplo de obstinação pela Educação e dedicação no Ensino de Desenho.

Ao Professor Marcelo Dreux, que sempre me estimulou e incentivou para que eu pudesse desenvolver este trabalho.

À professora Heloisa Fabiano dos Santos, que me fez acreditar que seria possível alçar voos mais altos e seguir em frente. 


\section{Resumo}

Projeções Ortogonais, processo fundamental para a elaboração de projetos em Desenho Técnico. Trata-se da planificação de peças, desenhos contendo as formas detalhadas e suas respectivas dimensões, de utensílios em geral, ferramentas, sistemas mecânicos, estruturas de construção civil, entre outros.

\section{Palavras-chave:}

Projeções Ortogonais; Planificação de um objeto; Sistema Mongeano de Projeção. 


\section{Epígrafe}

“O Desenho de Engenharia e a tecnologia gráfica constituem o principal método de comunicação em engenharia e em ciência e, como tal, interessa-se de um modo vital por todos os novos progressos".

A expressão gráfica do projeto de engenharia e construção pode muito bem ser o mais importante curso de todos os realizados para a formação de engenheiros ou de técnicos profissionais. A razão inquestionável por que a expressão gráfica é tão extremamente importante é que ela é a linguagem do projetista, do técnico e do engenheiro, utilizada para se comunicar projetos e pormenores de construção a outras pessoas. "(Thomas E. French., 1969)

\section{Introdução}

A partir do século XVIII, com o aperfeiçoamento das máquinas e sistemas mecânicos, o consequente aumento da complexidade dos seus mecanismos internos, linhas de produção, a necessidade de montagem e manutenção, da reposição de peças, da fabricação local de peças de reposição (longas distâncias inviabilizavam o envio de peças de reposição), entre outras inúmeras necessidades, levaram os projetistas a desenvolver uma técnica de desenho que se afastaria em definitivo do esboço artístico, muitos desenhos somente em perspectiva, para o desenho projetivo cilíndrico baseado na Geometria Descritiva, sistema desenvolvido pelo matemático francês Gaspard Monge no Século XVIII. 
As imagens, a seguir, exemplificam bem essa evolução. Desenho de Leonardo da Vinci. (Fig.1)

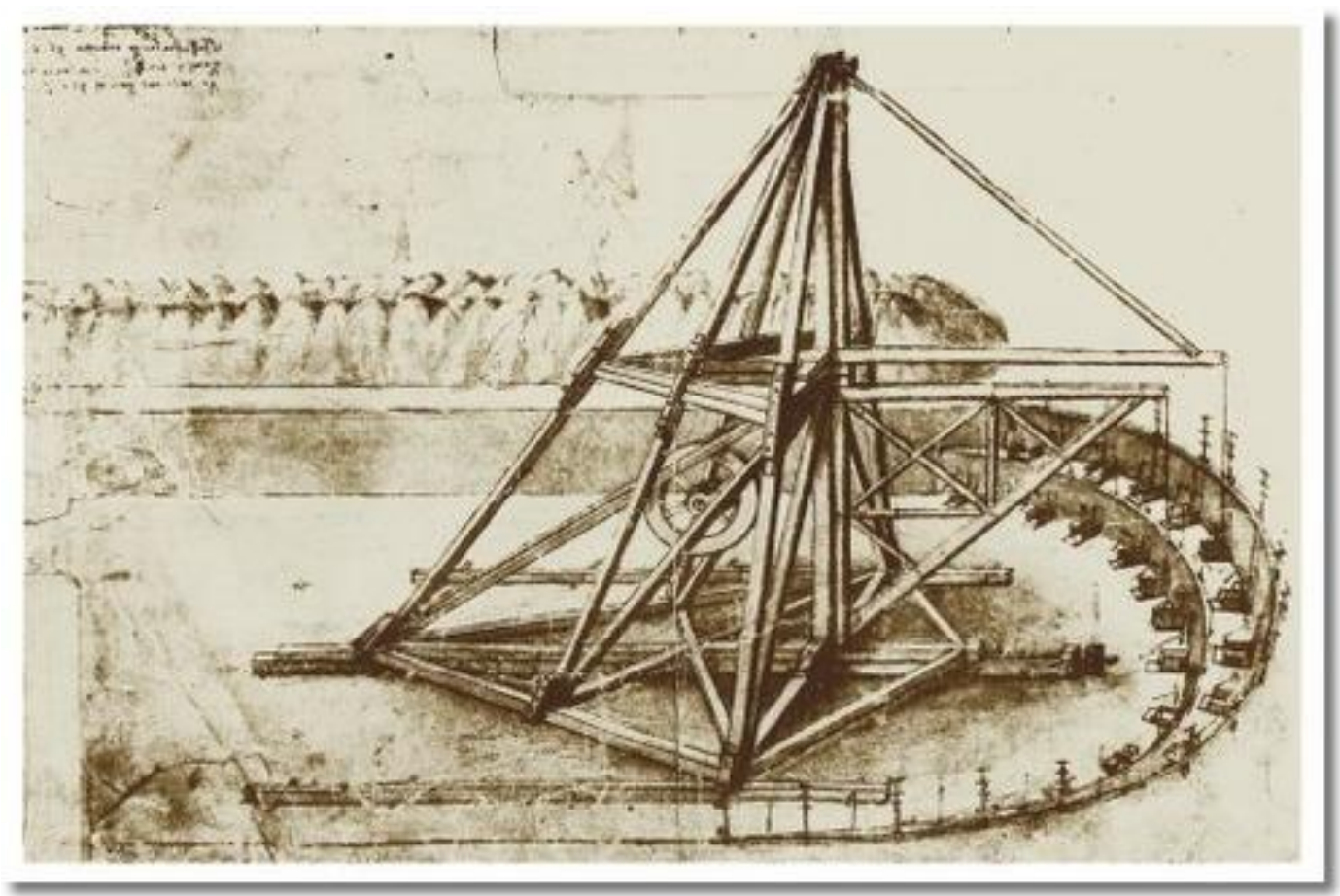

Desenhos em perspectiva de sistemas de moinhos. (Fig.2 e 2a)
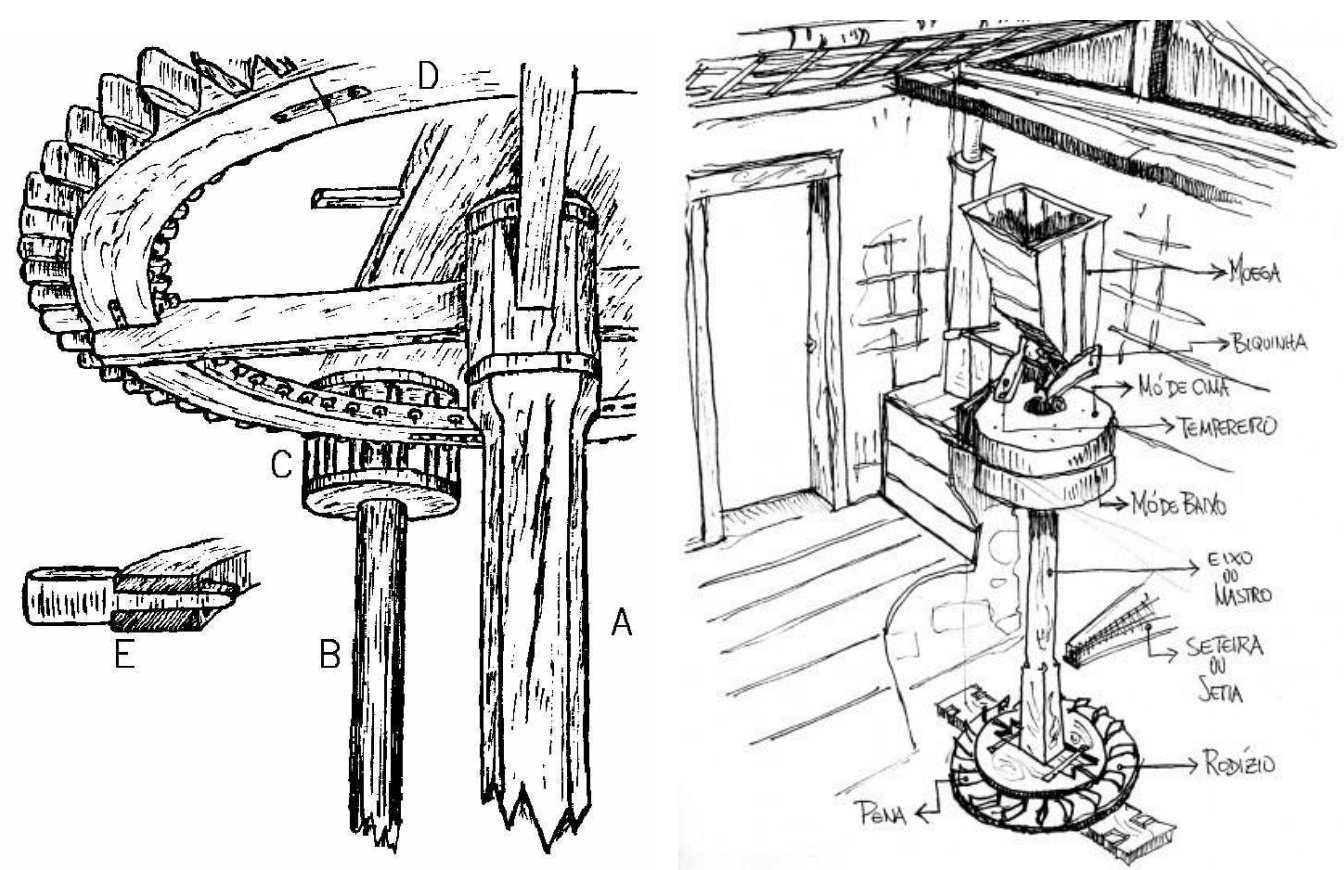
Turbina de uma máquina movida à vapor. (Fig3)

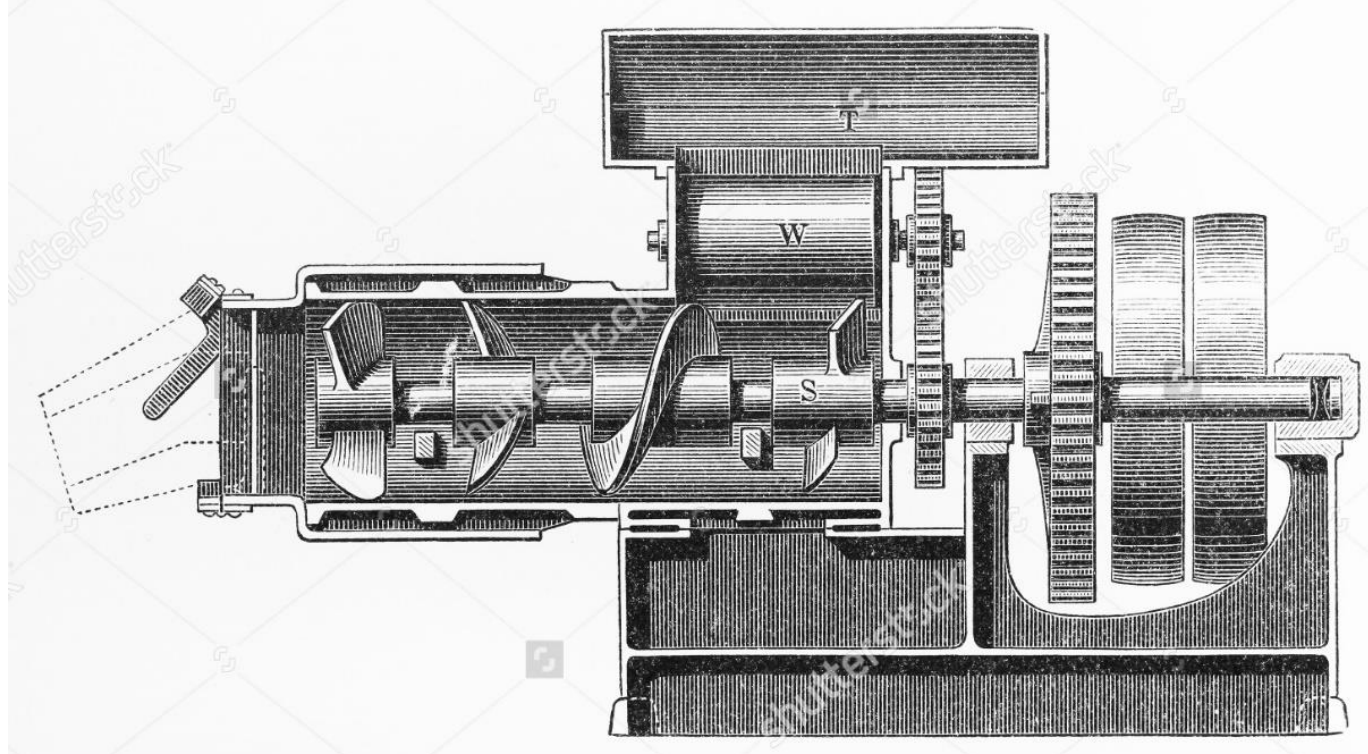

\section{shutterstrsck}

Desenho de uma requisição para patente de um automóvel. (Fig4)

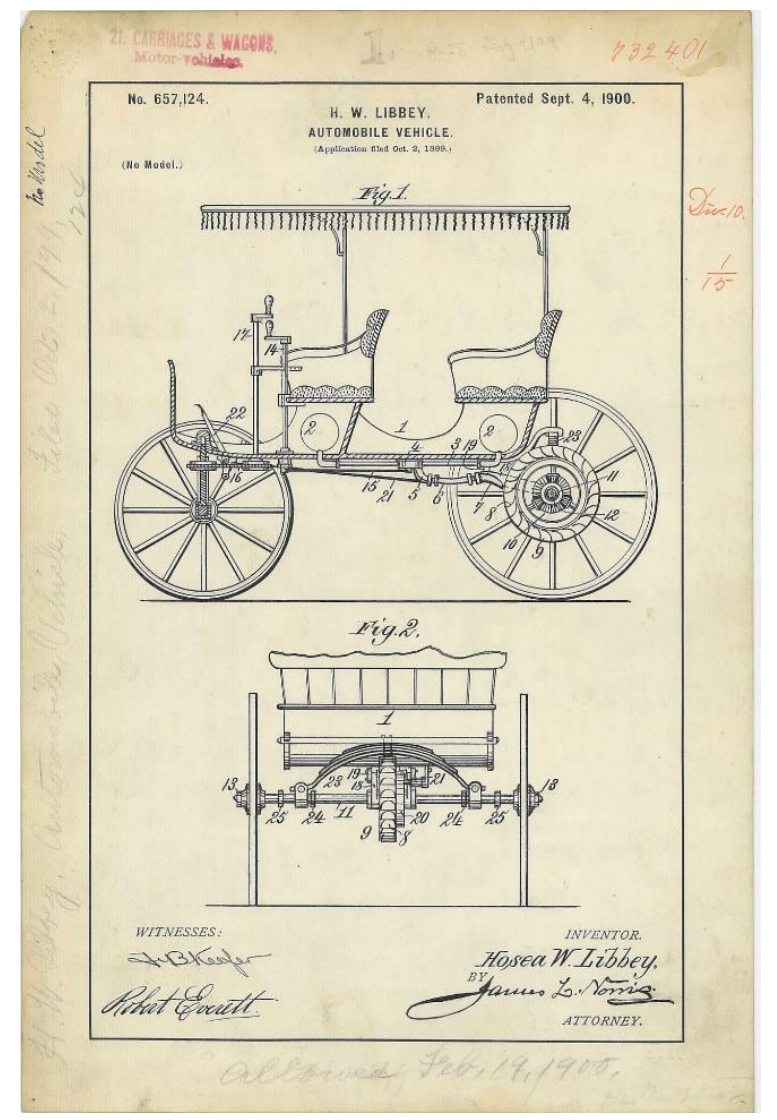


Desenho Técnico de uma peça em Perspectiva Isométrica e as suas respectivas Projeções Ortogonais no $3^{\circ}$ Diedro. (Fig.5)

2. Draw the views of the objects given below with sectional front view and sectional side view.
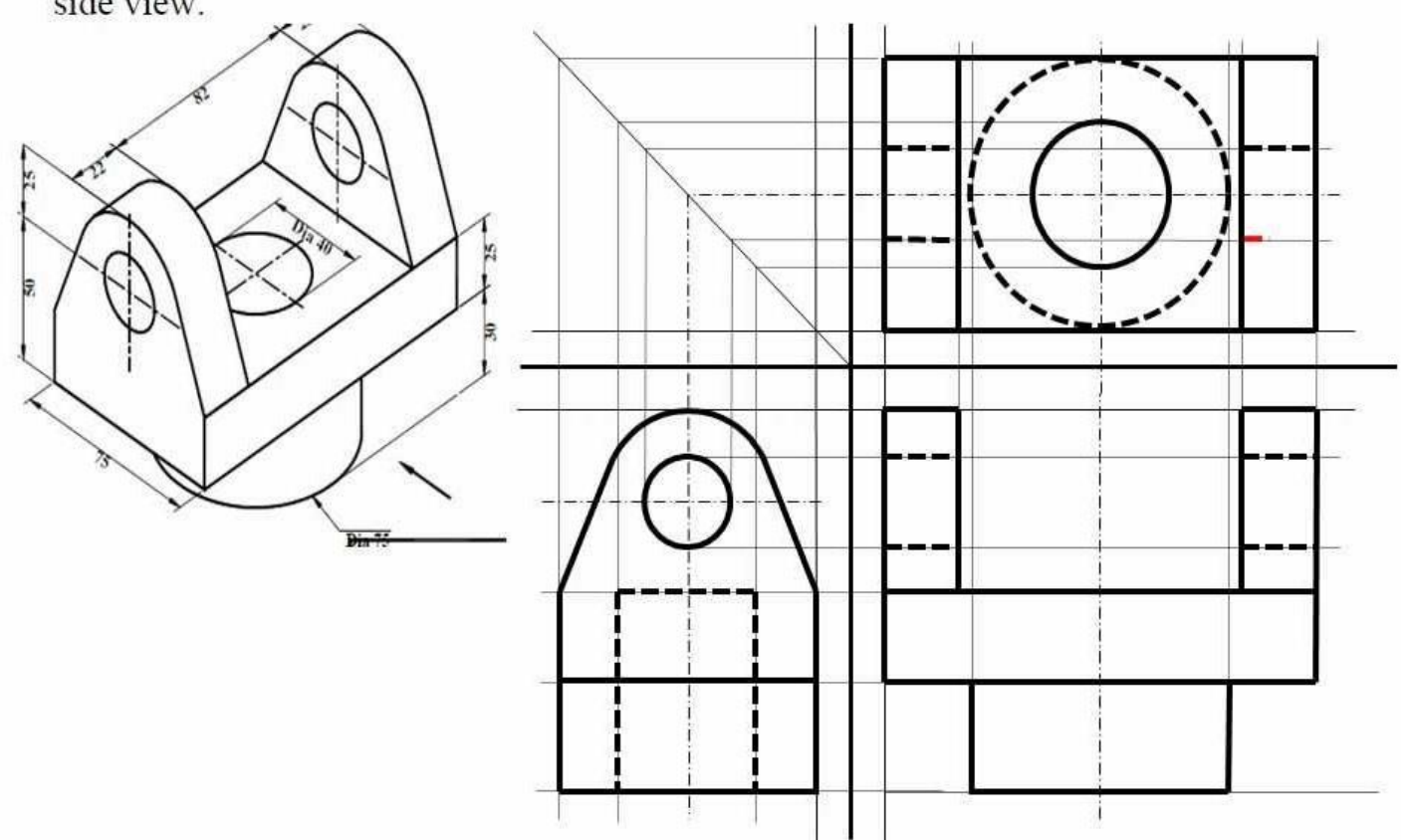

Meio corte de uma peça em vistas, utilizada para instrução, manutenção ou montagem. (Fig.6)

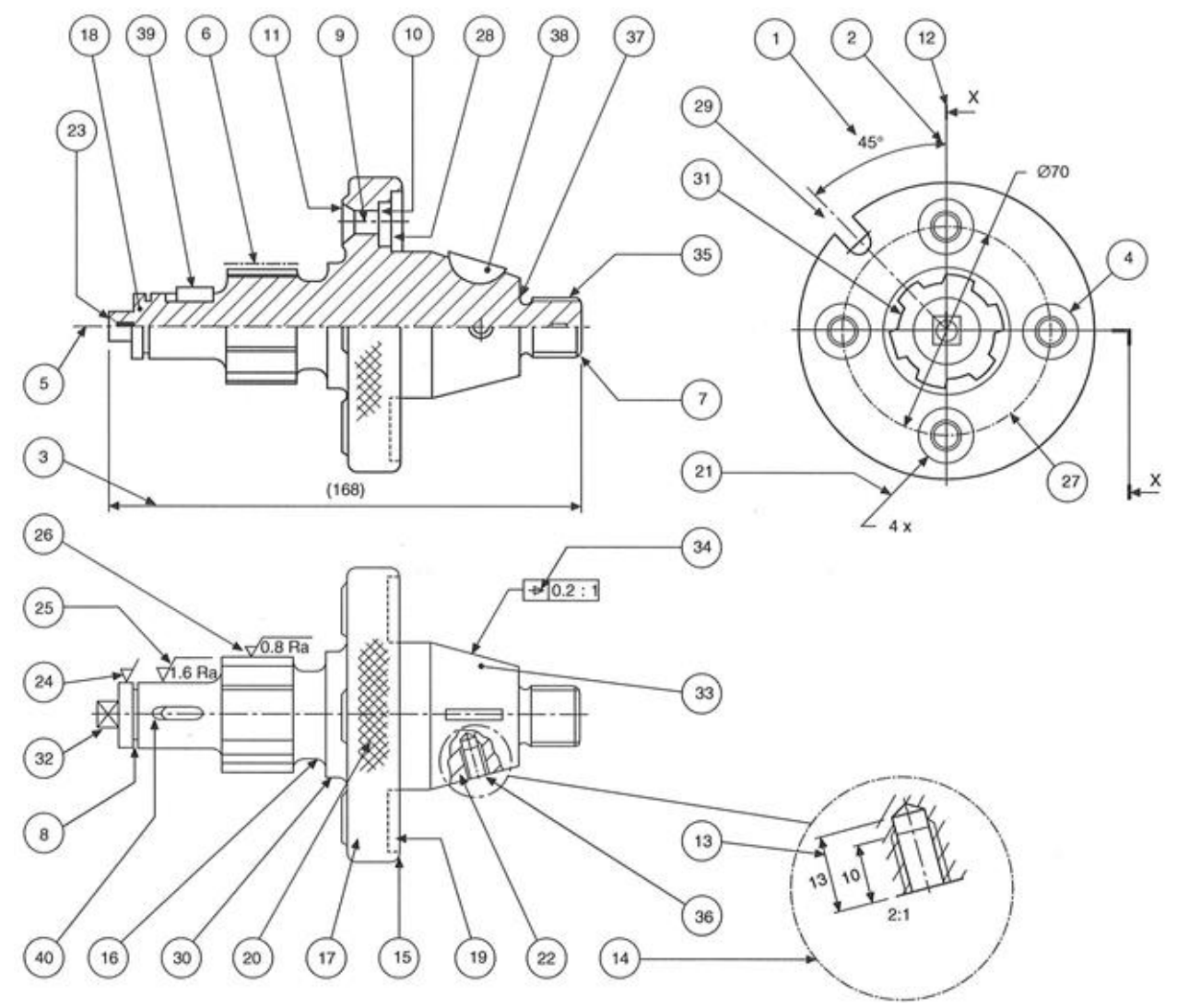




\section{Capítulo 1 Geometria Descritiva}

\section{Fundamentação Teórica}

“A Geometria é o ramo da Matemática que se propõe a estudar as figuras existentes na natureza através das propriedades de seus elementos, definindo, caracterizando e padronizando suas formas e dimensões, facilitando assim seu próprio desenvolvimento e o de outras áreas do conhecimento científico e tecnológico." (RABELLO, P.S.B., 2005)

Pré-requisito para o estudo das Projeções Ortogonais é o estudo da Geometria Descritiva. Os fundamentos do estudo do ponto e da reta no sistema mongeano é um facilitador para obter o entendimento do posicionamento das retas no espaço e suas respectivas projeções nos planos $\pi$ e $\Pi$ ', eventualmente o $\Pi$ " e posteriormente ver a épura resultante e os planos de perfil.

É baseado neste sistema, que ocorrem as Projeções Ortogonais, onde as vistas são projetadas sobre planos de projeção.

Considere dois planos de projeção, ortogonais entre si. Um é vertical outro horizontal. Os planos dividem o espaço em quatro regiões, denominadas diedros.

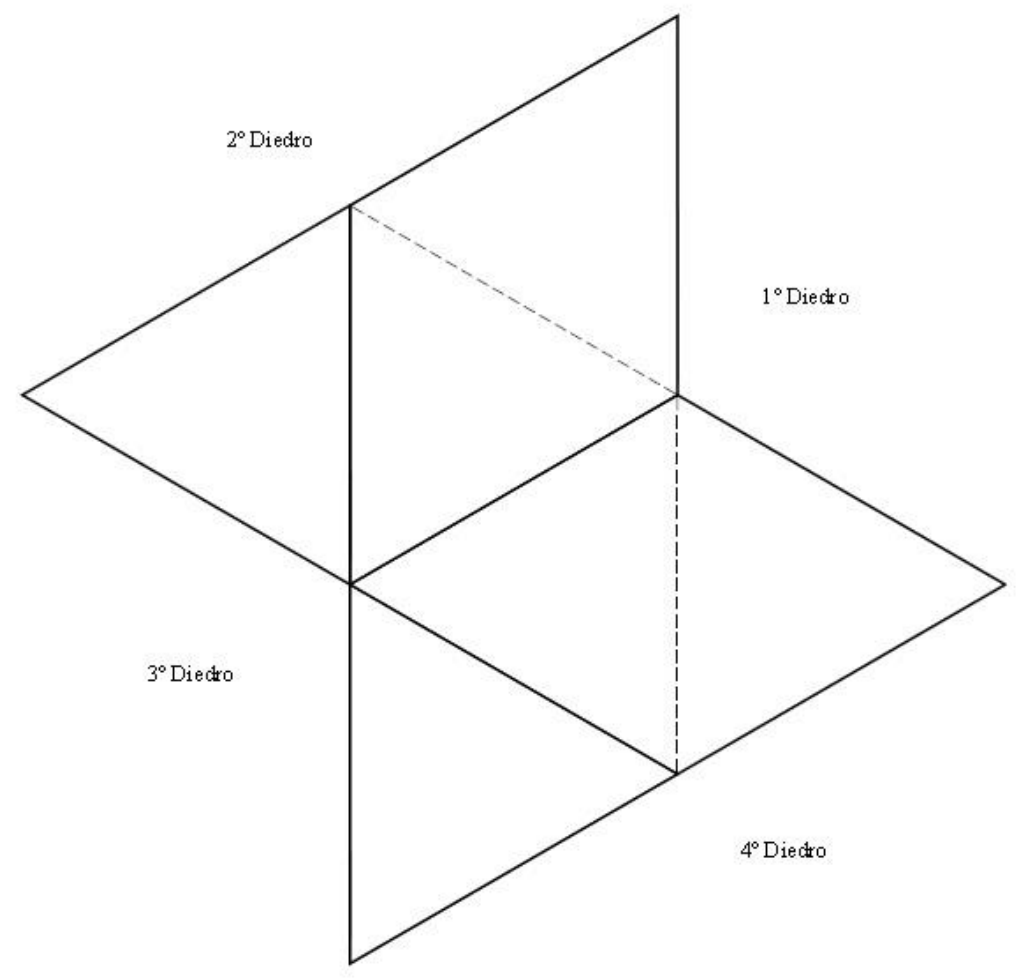


A linha resultante da intercessão dos dois planos é chamada de Linha de Terra. No plano vertical ( $\left.\Pi^{\prime}\right)$ temos a dimensão COTA, que será positiva quando o ponto de estudo estiver acima da LT, e negativa quando estiver abaixo da LT. No plano horizontal (ח) temos a dimensão AFASTAMENTO, que será positiva quando o ponto estiver antes da LT e negativa quando estiver depois da LT. Sobre a LT temos a dimensão ABCISSA.

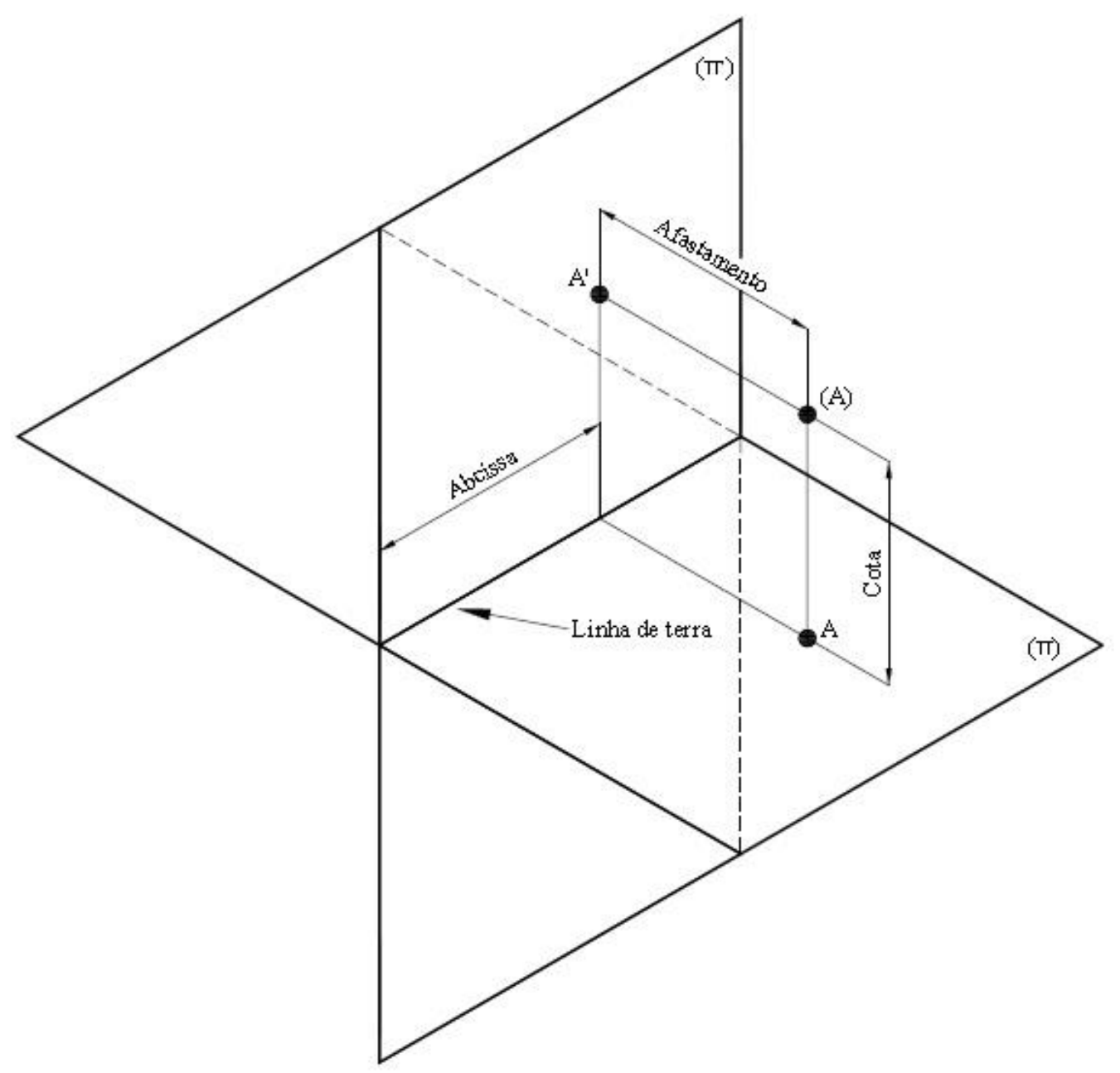

As três dimensões, Abcissa, Afastamento e Cota determinam a posição de um ponto no Sistema Mongeano de Projeção. Para simplificar, usaremos X, Y e Z para Abcissa, Afastamento e Cota. 
Será realizado o rebatimento do plano horizontal, girando o mesmo sobre a LT de forma que os planos $(\pi)$ e ( $\Pi$ ') fiquem coincidentes.
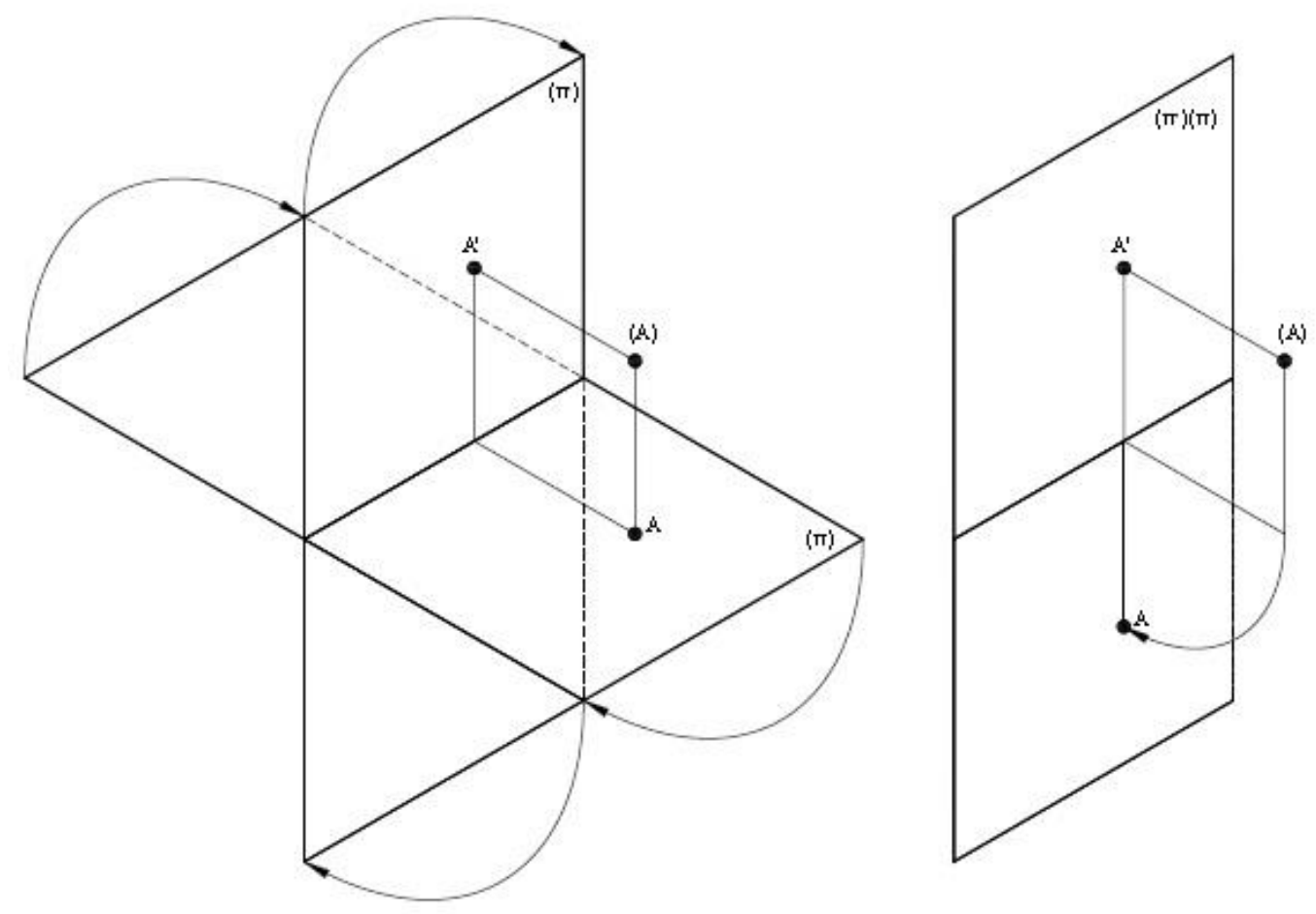

Obtém-se a Épura e os Planos em Perfil.
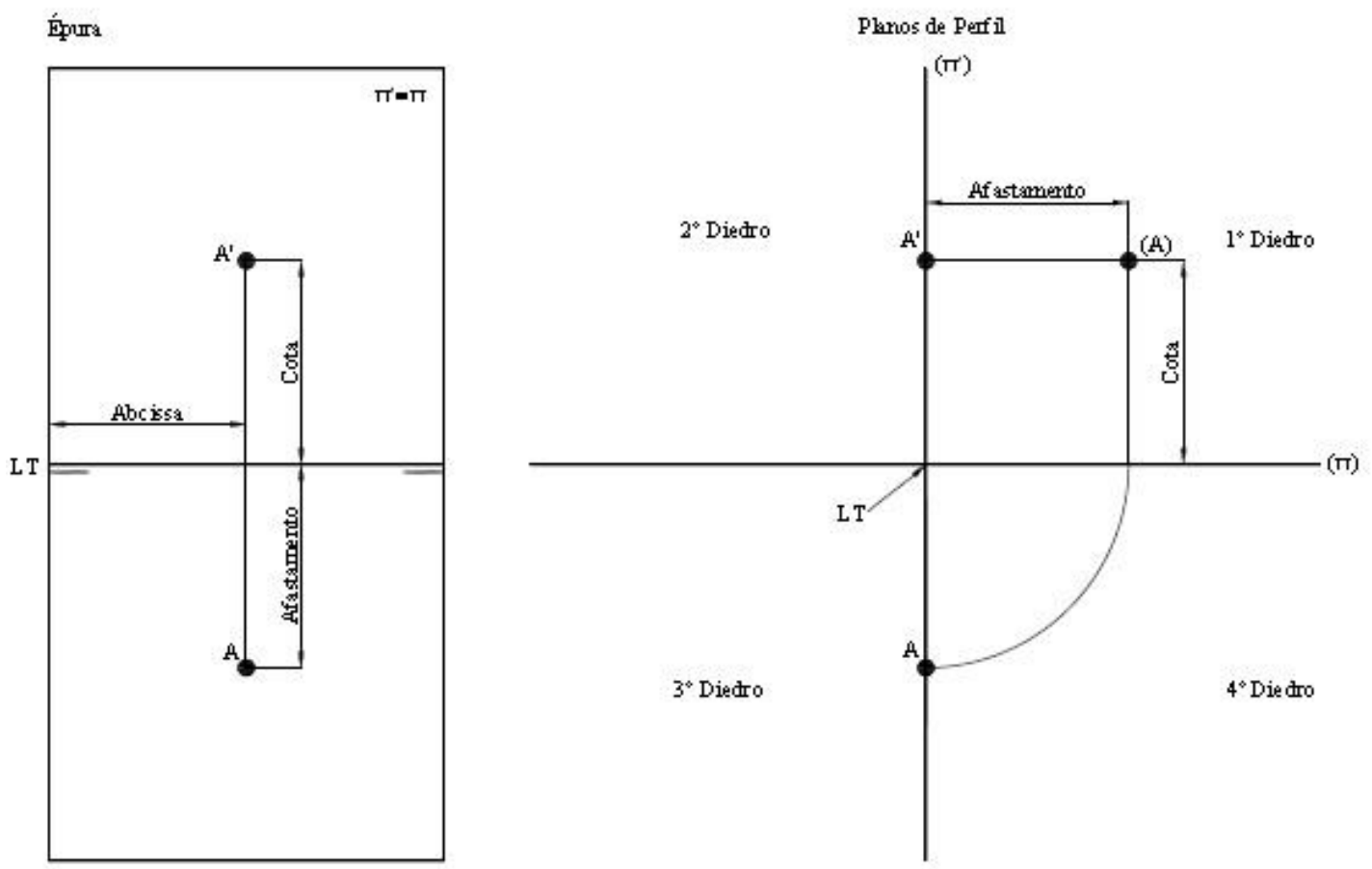
A partir do estudo do ponto, podemos introduzir o estudo das retas, tendo como referência as faces de um hexaedro regular.

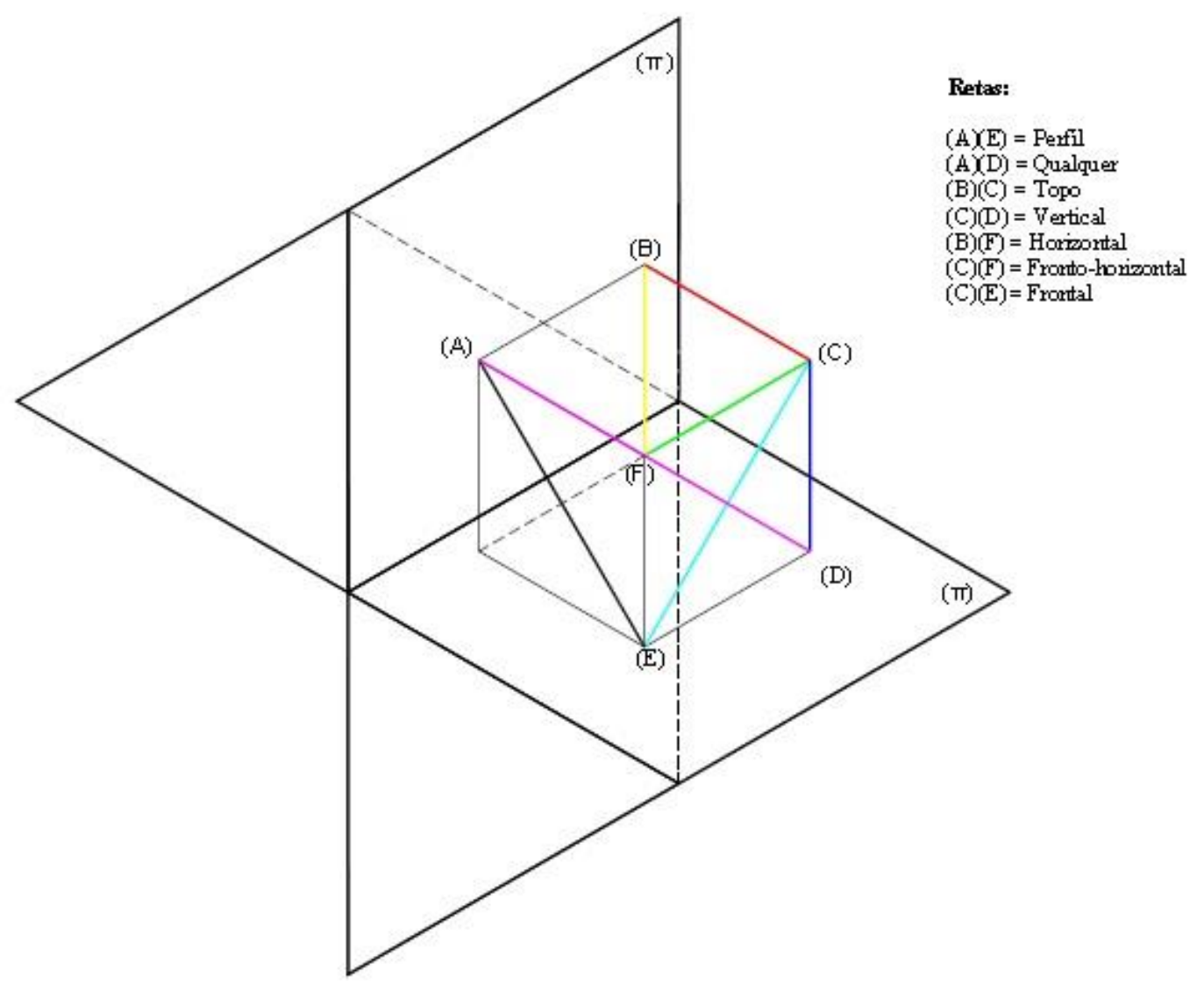




\section{Capítulo 2 Projeções Ortogonais}

"A projeção ortogonal é a representação de um objeto em um plano de projeção, quando as linhas visuais são perpendiculares a este plano. " (HOELSCHER, R.P.; SPRINGER, C.H.; DOBROVOLNY, J.S., 1978 )

"A projeção ortográfica é o método de representar a forma exata de um objeto por meio de duas ou mais projeções do objeto sobre planos que, em geral, estão em ângulo reto entre si baixando-se perpendiculares do objeto ao plano. $O$ conjunto das vistas sobre esses planos descreve totalmente o objeto." (FRENCH, T.E.; VIERCK, C.J. , 1985)

Uma das etapas mais importantes para a formação do engenheiro, é capacita-lo no processo de ler e escrever em desenho projetivo. O processo é simples, e a execução igualmente simples, os contornos que dão forma ao objeto são projetados sobre uma superfície de projeção, a dificuldade surge quando o objeto tem mais de uma elevação, em relação à superfície de projeção, ou está inclinado ou tem forma cilíndrica.

O sistema de projeção consiste em um ponto de luz colocado no infinito que "ilumina" uma das superfícies a ser projetada. Esta primeira superfície será denominada de Vista Frontal (é mais importante, que contém o maior número das características físicas de identificação da peça). As demais vistas são denominadas Lateral e Superior.

Uma peça simples, de fácil interpretação, é apresentada em perspectiva isométrica, tendo suas faces formando ângulos de 90 graus entre si. 
Partimos de um objeto para planificação.

Vistas Ortográficas Ргојeção Ortogonal no $1^{\circ}$ Diedro Capítulo 10 (ABNT 10067)

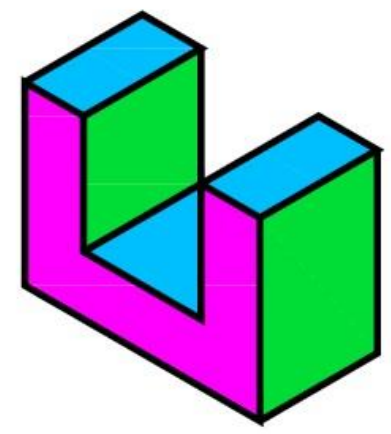

Objeto em Perspectiva

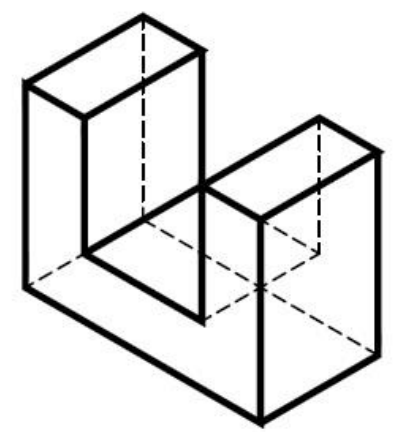

Arestas que definem 0 objeto

Este objeto é colocado em uma "caixa" prismática perfeitamente translúcida. (Fig.8)

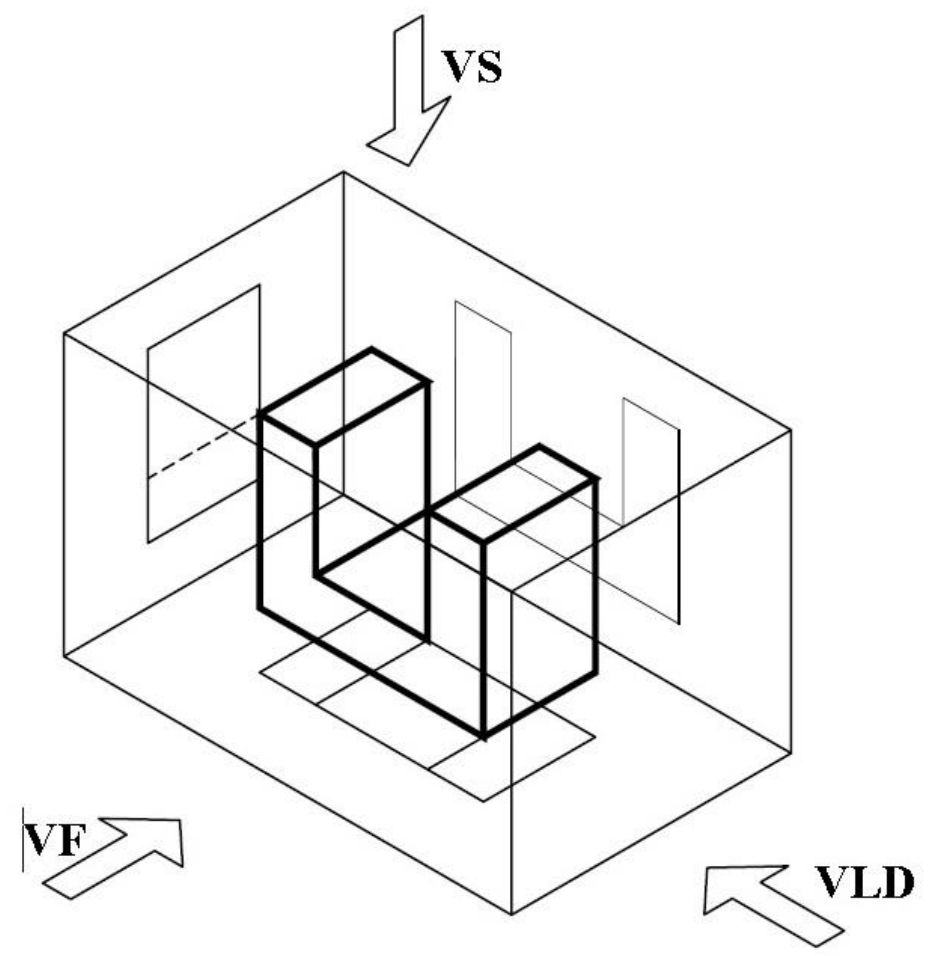

Método do Sólido Envolvente 
As setas indicam as respectivas direções para geração das projeções da Vista Frontal, Vista Lateral Direita e Vista Superior.

A caixa é então aberta, tendo as superfícies que não tem projeção, descartadas. (Fig.9)

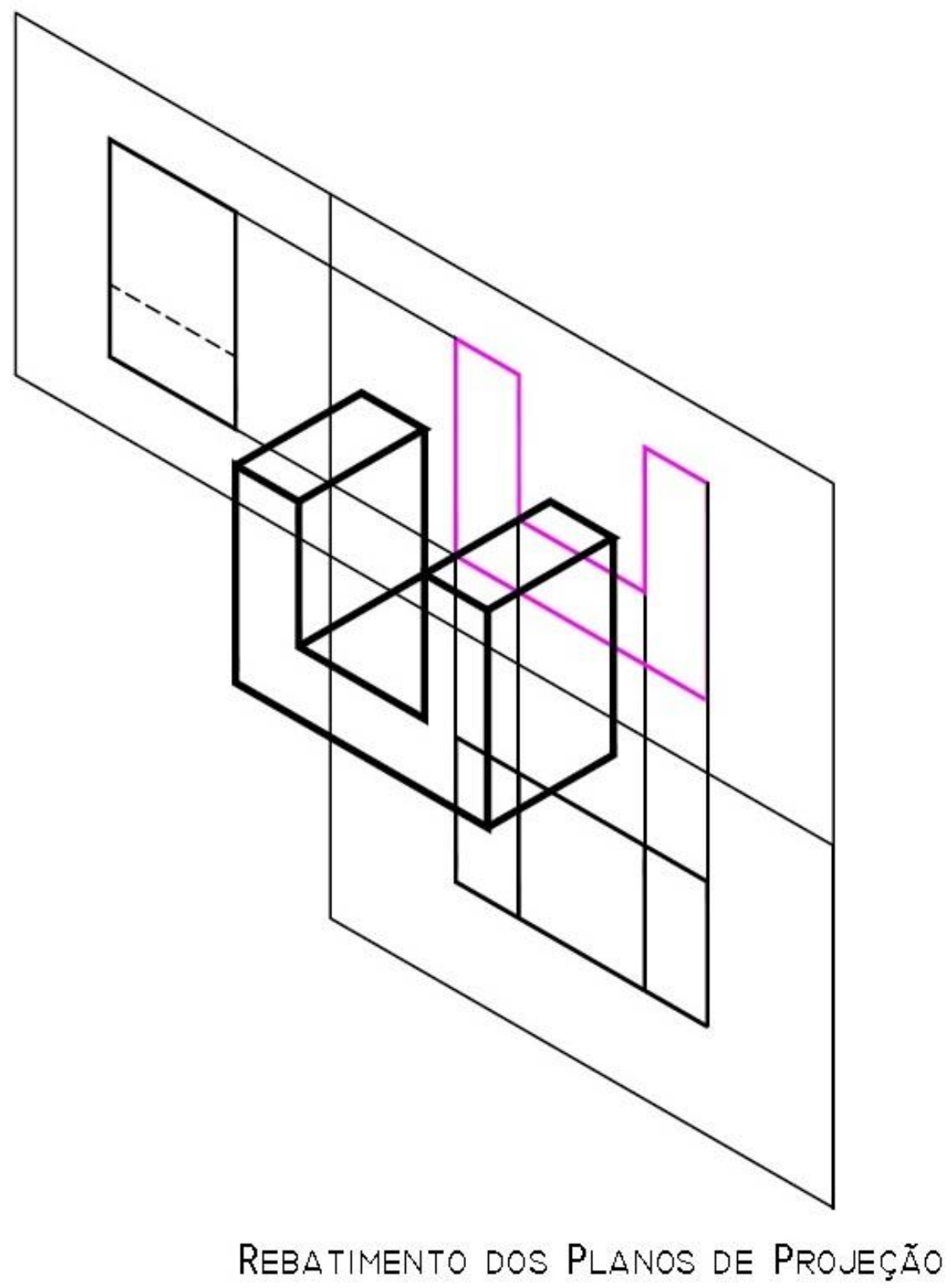

O plano de projeção à esquerda da Vista Frontal contém a projeção da Vista Lateral Direita, assim como o plano de projeção abaixo da Vista Frontal contém a projeção da Vista Superior. 
O objeto de estudo é retirado, ficando somente os planos com as projeções. (Fig.10)

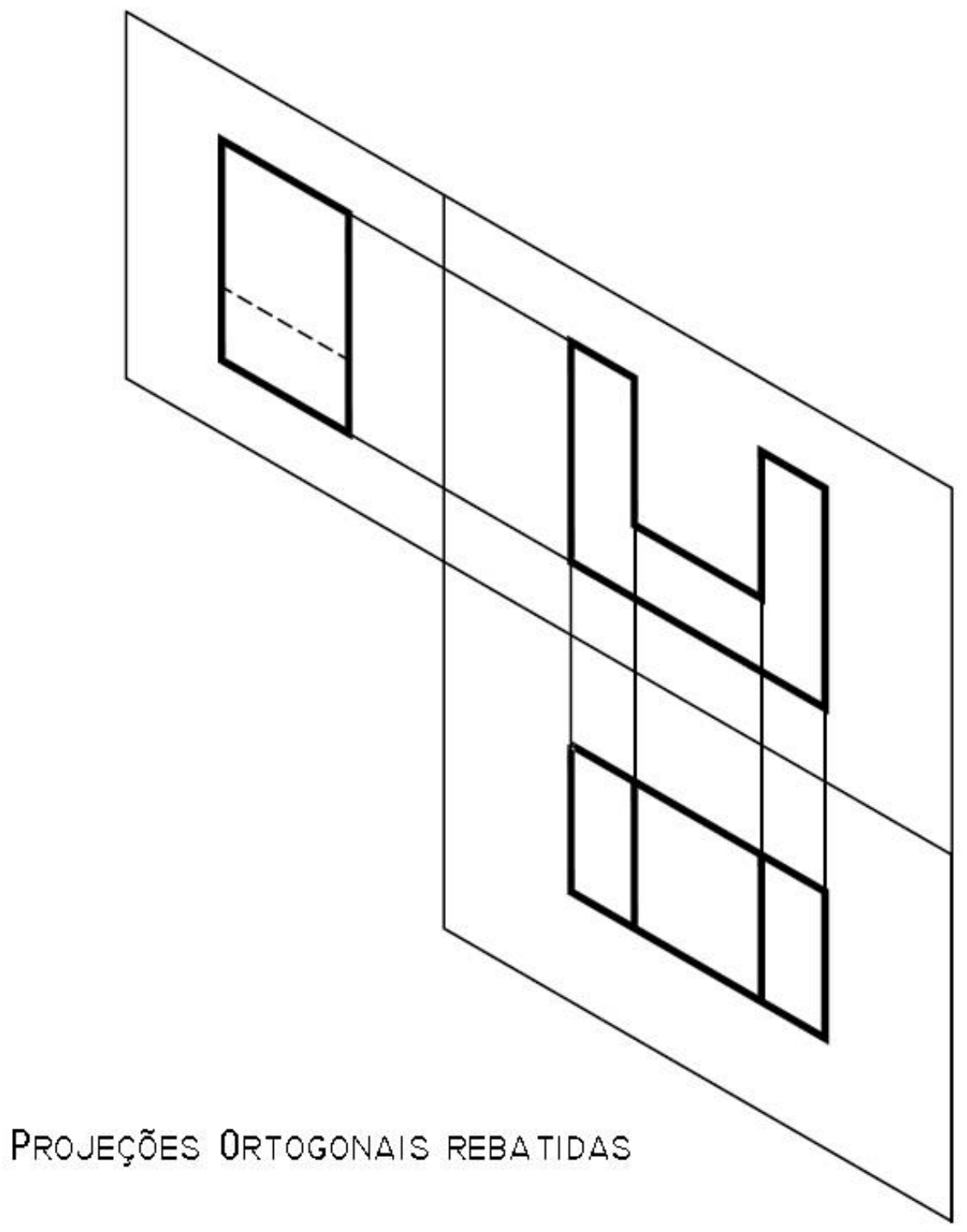


Por fim, corrigindo o efeito da Perspectiva, as Vistas resultantes são colocadas de frente para o Observador.

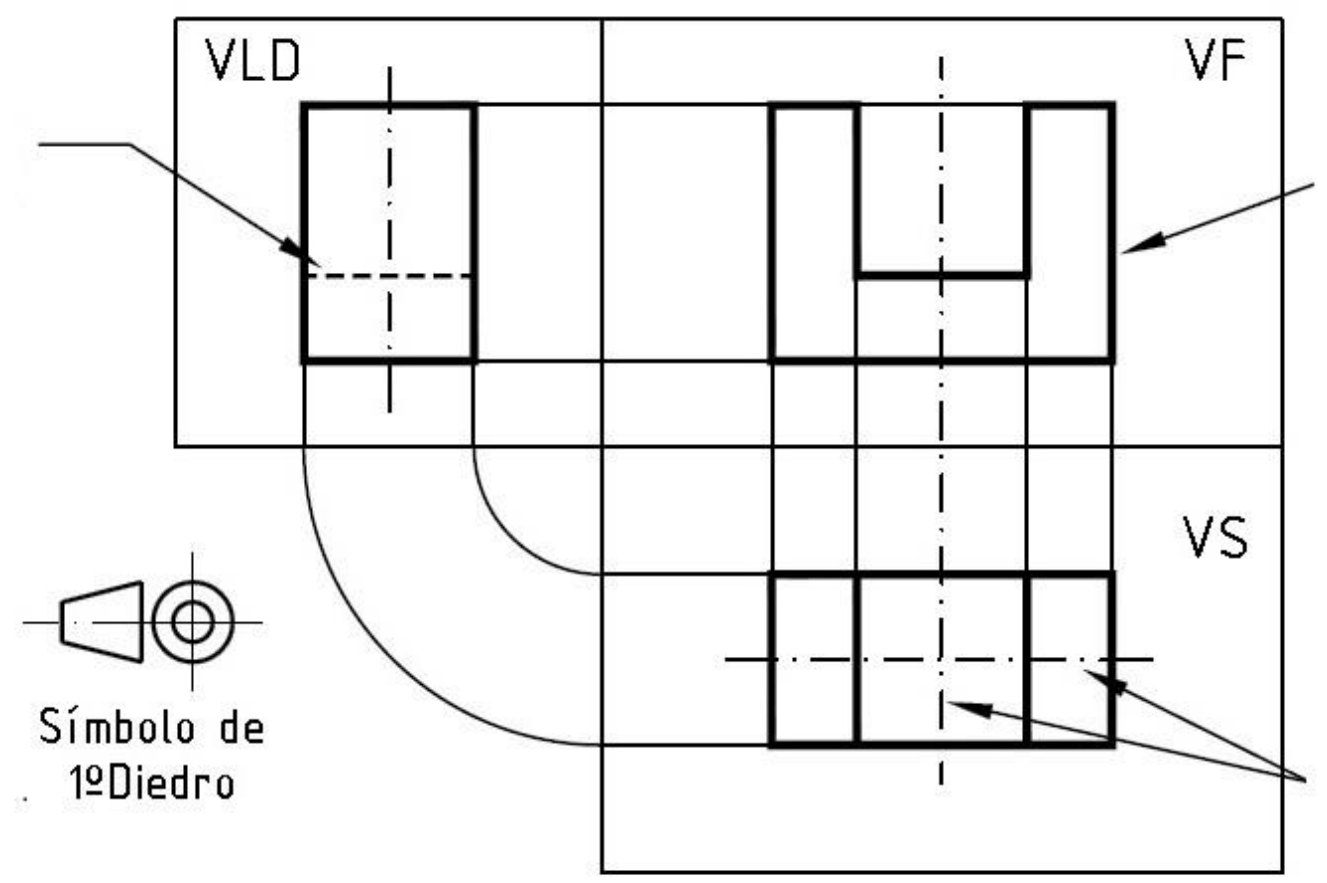

Vistas Ortográficas Principais

O resultado final do processo é a obtenção das vistas ortográficas principais de um objeto tridimensional.

As setas indicam os três tipos de linhas empregados para a execução do desenho, sendo:

- Tracejada - De espessura média, arestas invisíveis.

- Contínua - De espessura grossa, arestas visíveis.

- Traço-ponto - De espessura fina, eixo de simetria.

A Norma Técnica 10067 é específica da ABNT para "Os Princípios Gerais para Representação em Desenho Técnico”. 


\section{Desenvolvimento}

O princípio do sistema de Projeções Ortogonais consiste em um ponto de luz colocado no infinito, uma peça de estudo e um plano opaco. A peça é iluminada pelo ponto de luz e uma sombra surge, em decorrência da luz emitida, esta sombra é projetada sobre o plano opaco. (Fig.7)

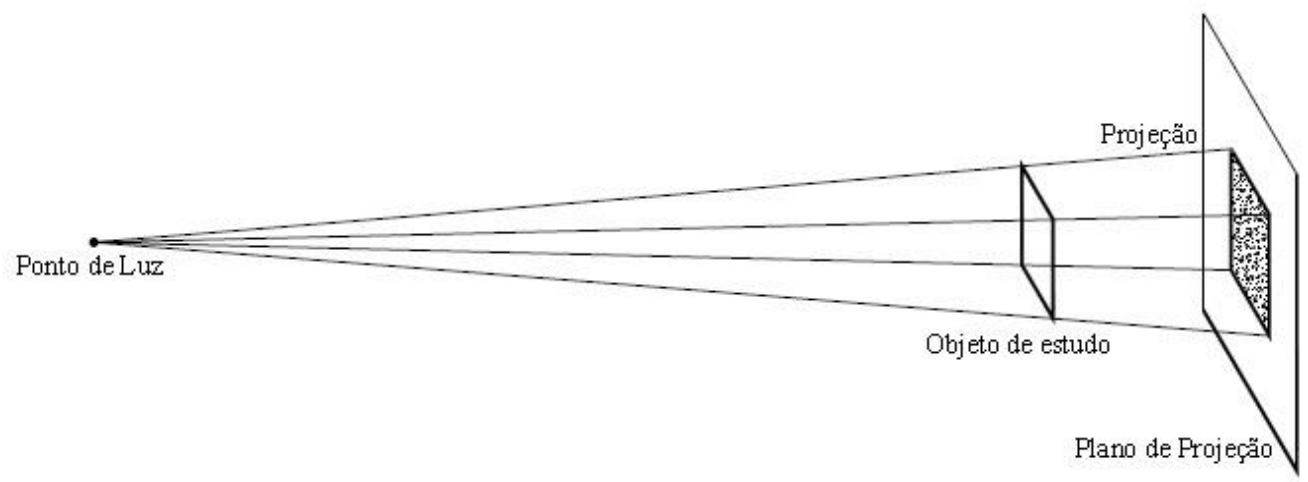

A fim de compensar possíveis deformações dimensionais, mesmo que proporcionais, colocaremos o ponto emissor de luz no infinito, Projeções Cilíndricas ${ }^{1}$, passando os raios de luz à posição ortogonal ao plano de projeção. (Fig.8)

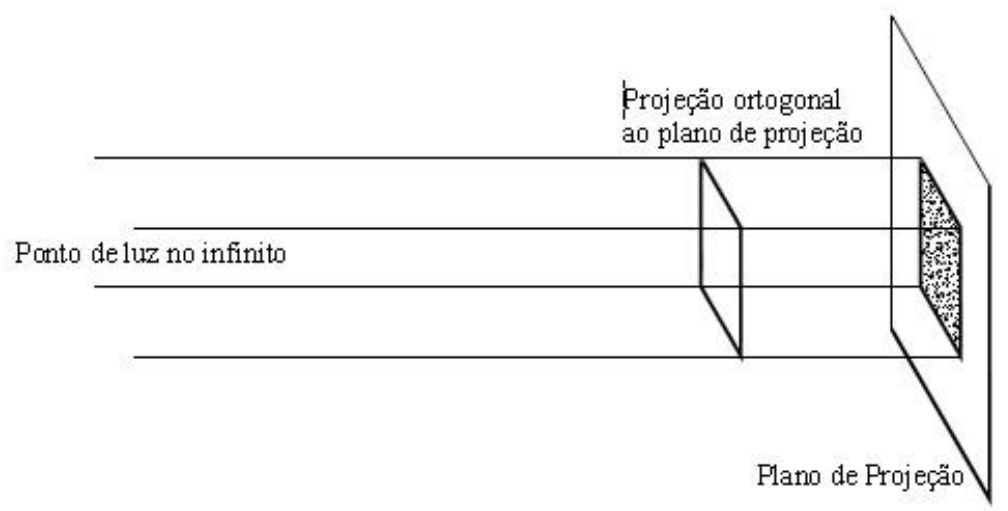

Até o presente, o objeto de estudo corresponde a uma das faces de um hexaedro regular, sendo, portanto, bidimensional.

(1.)Quando se considera impróprio o centro de projeção, o sistema de representação que ele constitui com o plano projetante, denomina-se cilíndrico. 
Será introduzido um objeto com três dimensões onde o Sistema de Projeções Ortogonais aplicada. Três pontos de luz, colocadas no infinito, iluminarão as três faces visíveis da peça e por consequência, serão geradas três projeções sobre os três planos de projeção. Cada ponto emissor de luz terá uma cor, verde para a que denominaremos Vista Frontal, vermelha para a Vista Lateral e Azul para Vista Superior.

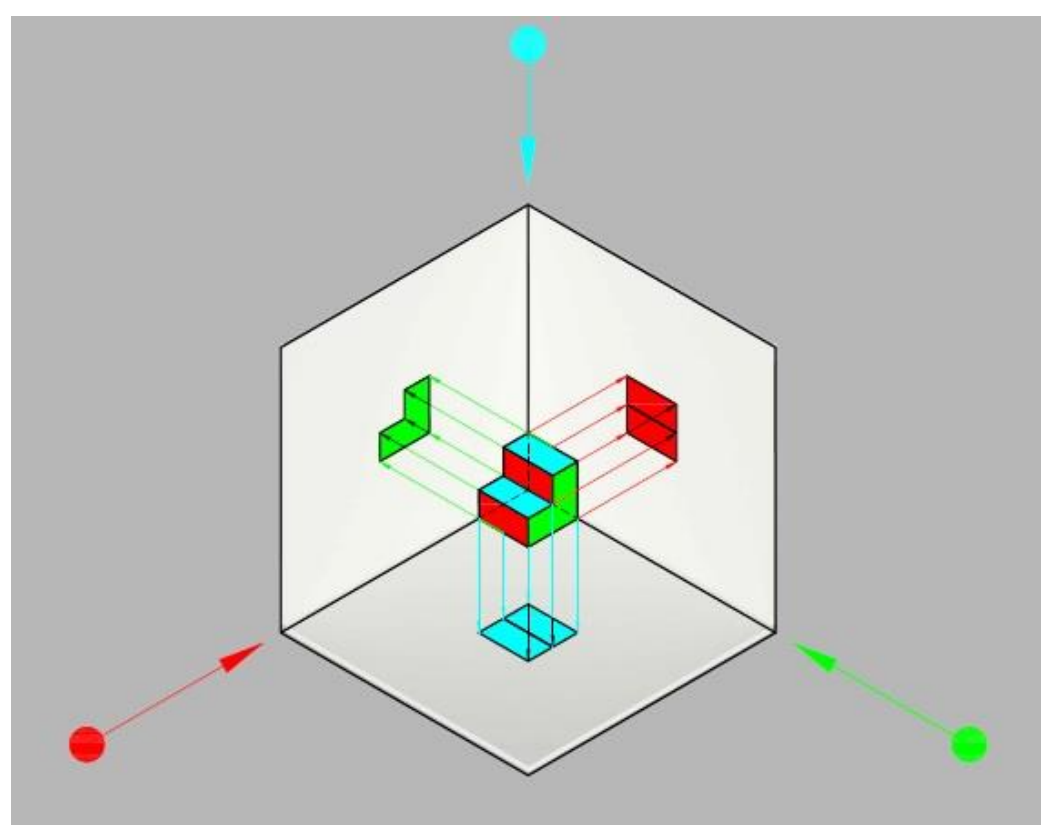

O passo seguinte será o rebatimento do plano auxiliar ( $\Pi$ "), progressivamente, até que este plano fique alinhado, coplanar, ao plano $\left(\pi^{\prime}\right)$.

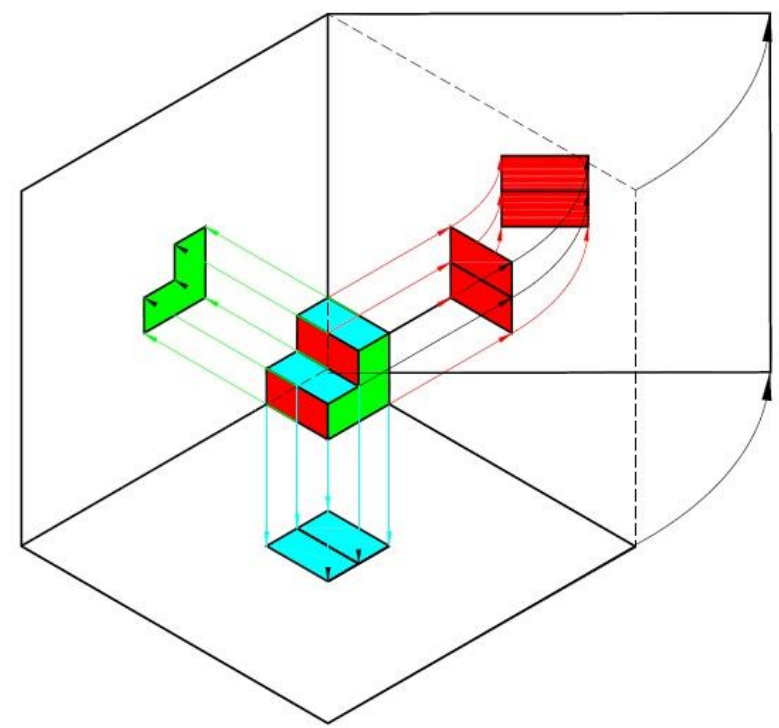




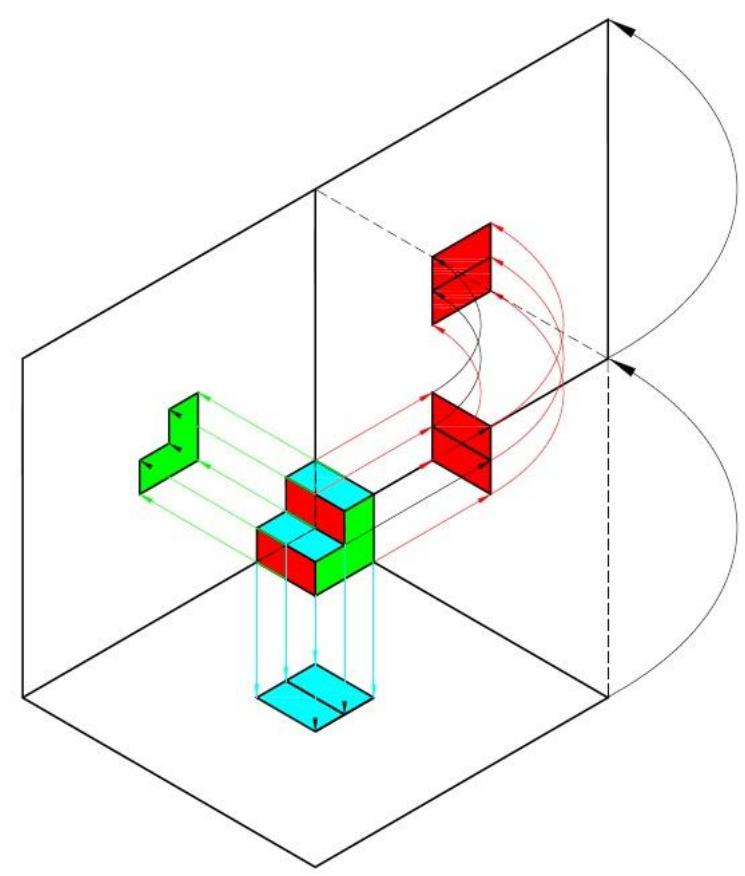

O passo seguinte será o rebatimento do plano $(\pi)$, progressivamente, até que este plano fique alinhado, coplanar, ao plano $\left(\pi^{\prime}\right)$.

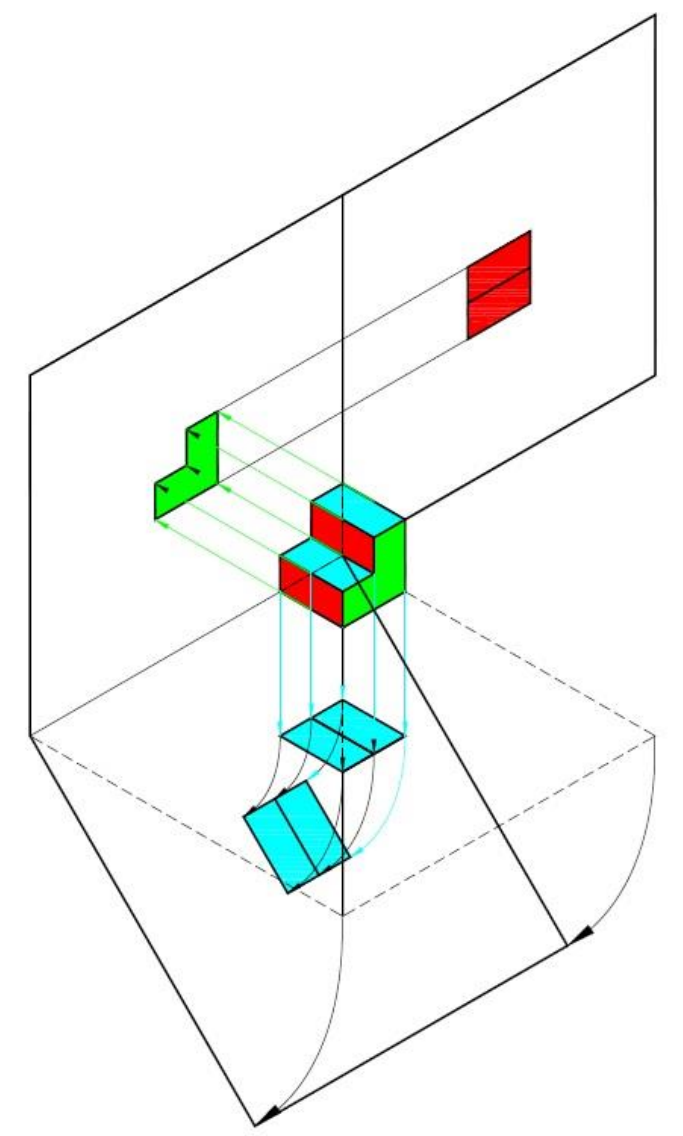


Finalmente, temos os planos contendo a Vista Lateral e a Vista Superior rebatidos.

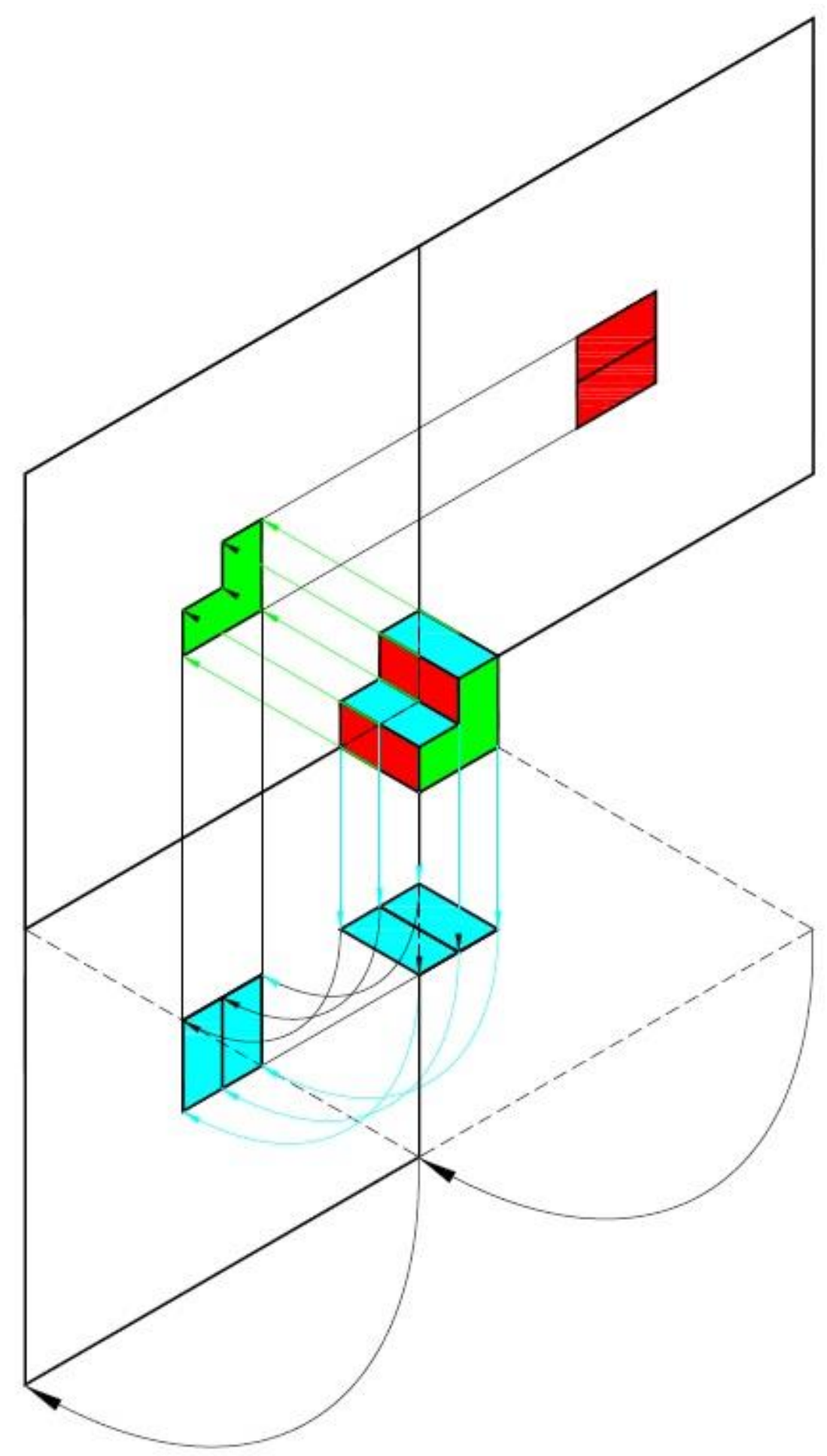


Peça retirada, ficando somente as projeções.

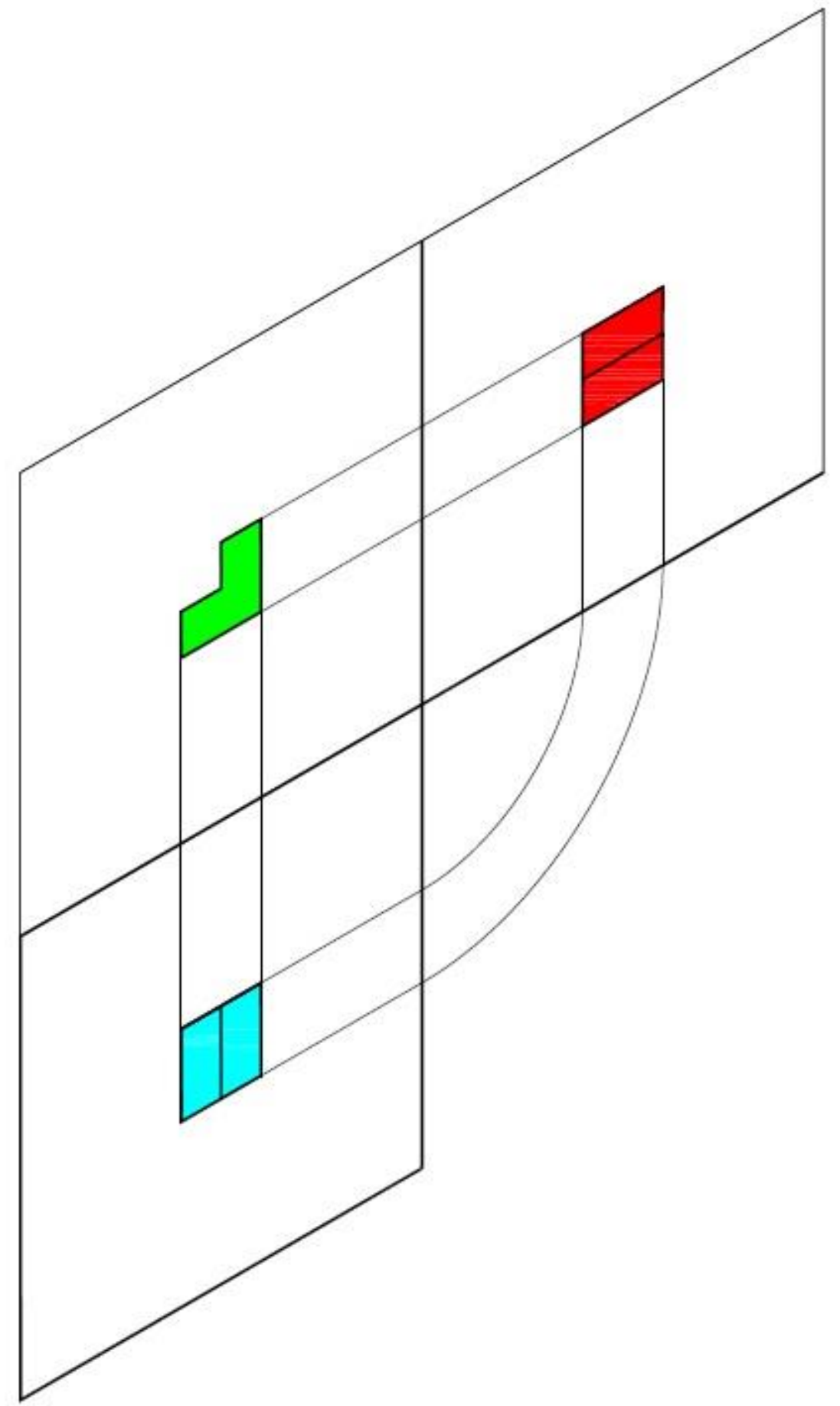


Após corrigir o ponto de vista, temos:

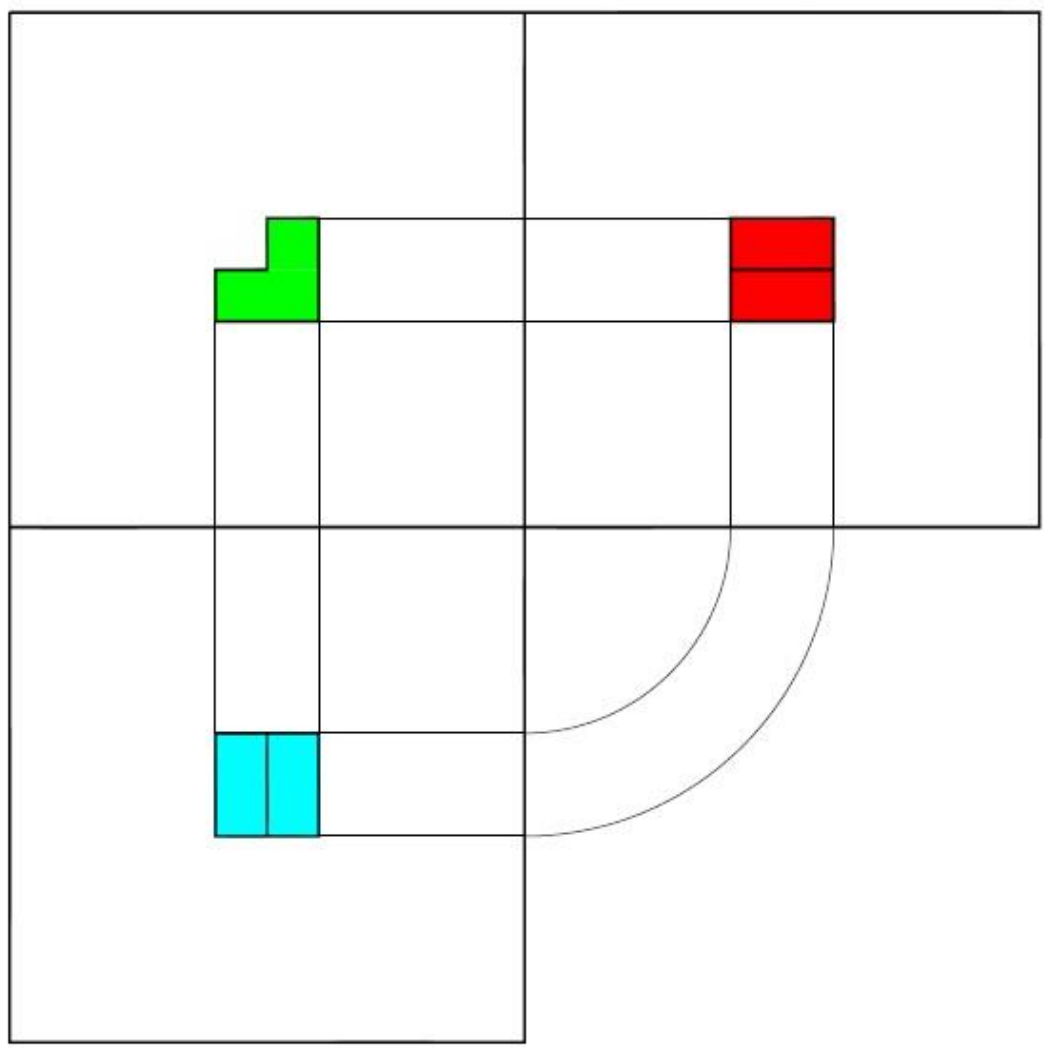

Abaixo uma imagem em CAD com a VF e a VL.

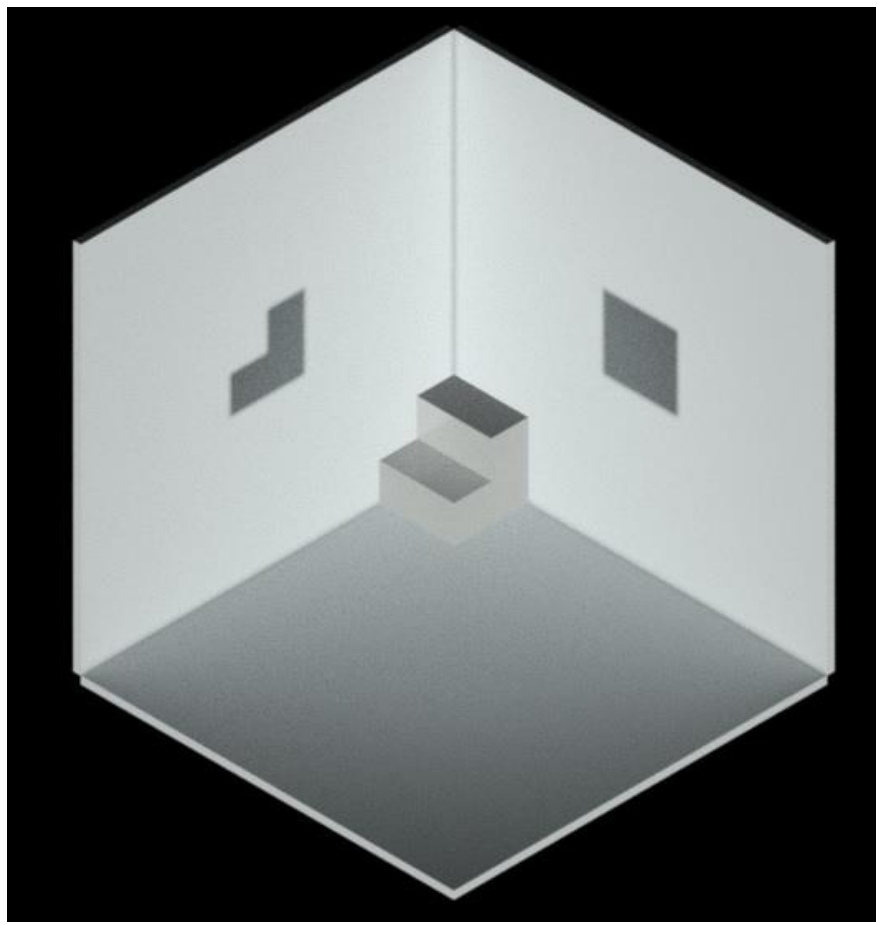


Peça colorida em CAD com as três projeções.

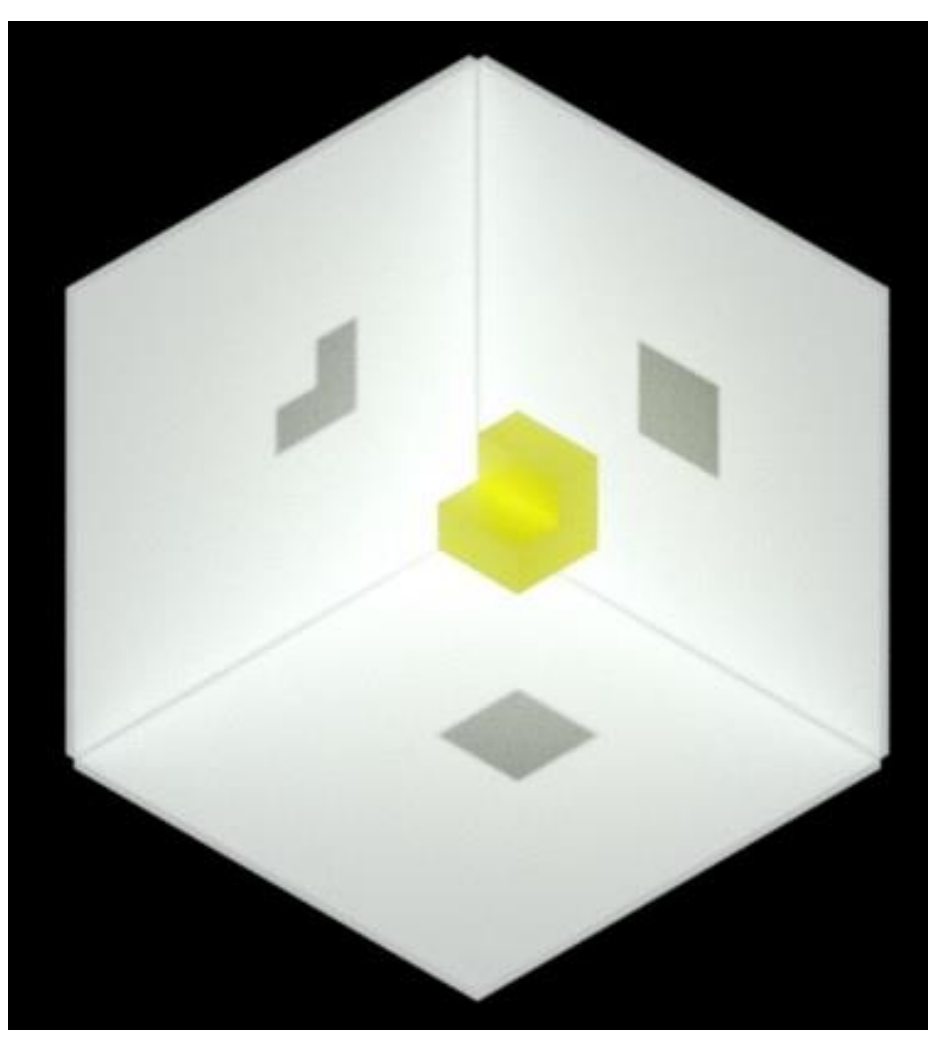

Somente a VF.

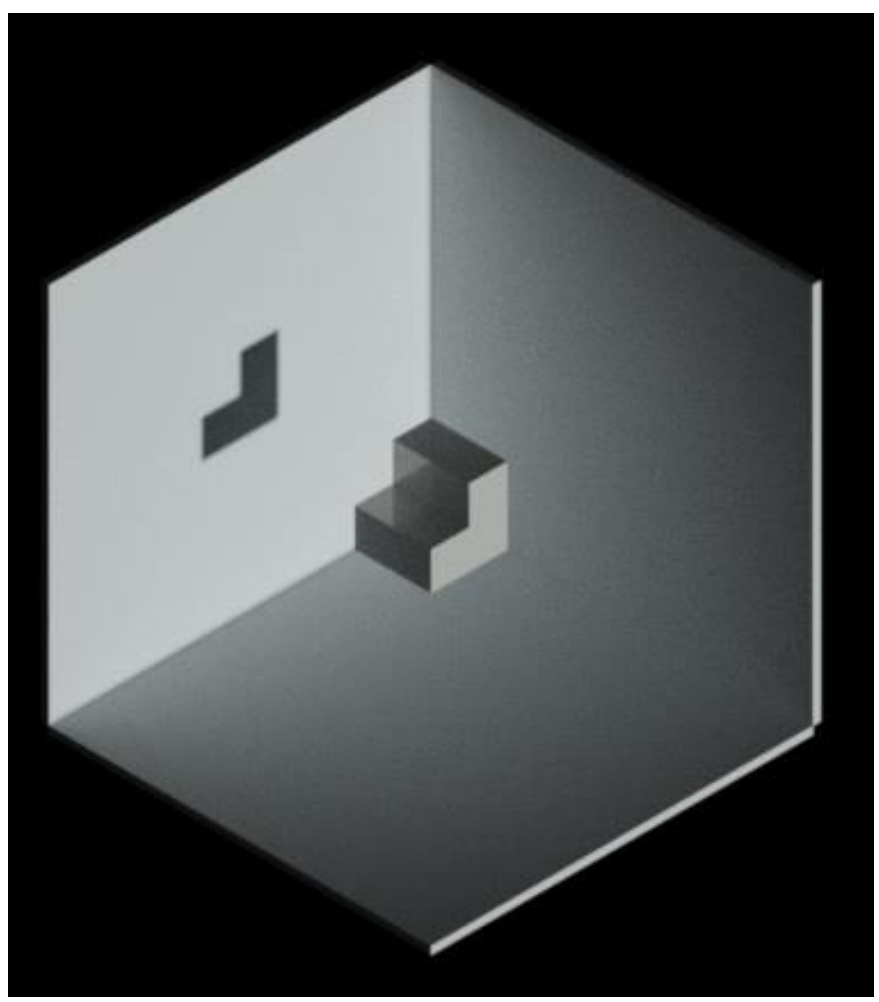




\section{Capítulo 3 Percepção Visual}

“A orientação espacial pressupõe uma moldura de referência” (Arnheim, R. 2004)

Um aspecto intrigante do Curso de Desenho Técnico, e a forma com que alguns alunos resolvem os exercícios propostos. Ao fim da demonstração da aula, na questão teórica da exposição do Sistema de Projeções Ortogonais, 100\% dos alunos sinalizam que compreenderam a teoria e se dizem prontos para desenvolver, junto com o professor, um exercício proposto. Na prática, a grande maioria vai muito bem, porém alguns alunos têm grande dificuldade de perceber que a visão relativa deve se adequar ao ponto de vista relativo à Vista Frontal, Vista lateral e Vista Superior.

A seguir, um exemplo de dois exercícios propostos e a solução esperada. O enunciado pede que o aluno represente das Vistas Ortográficas das peças, observando a seta que indica a posição da Vista Frontal.

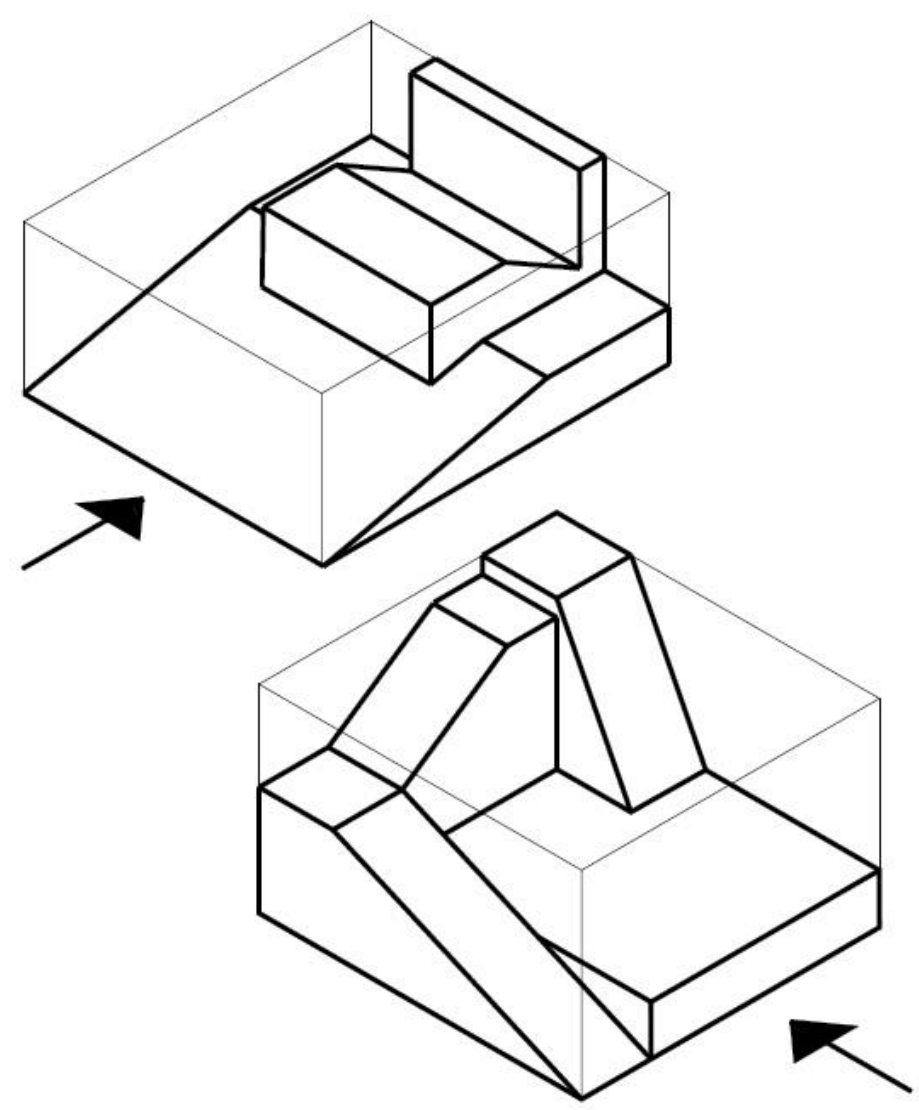


Abaixo a solução esperada para o primeiro exercício:

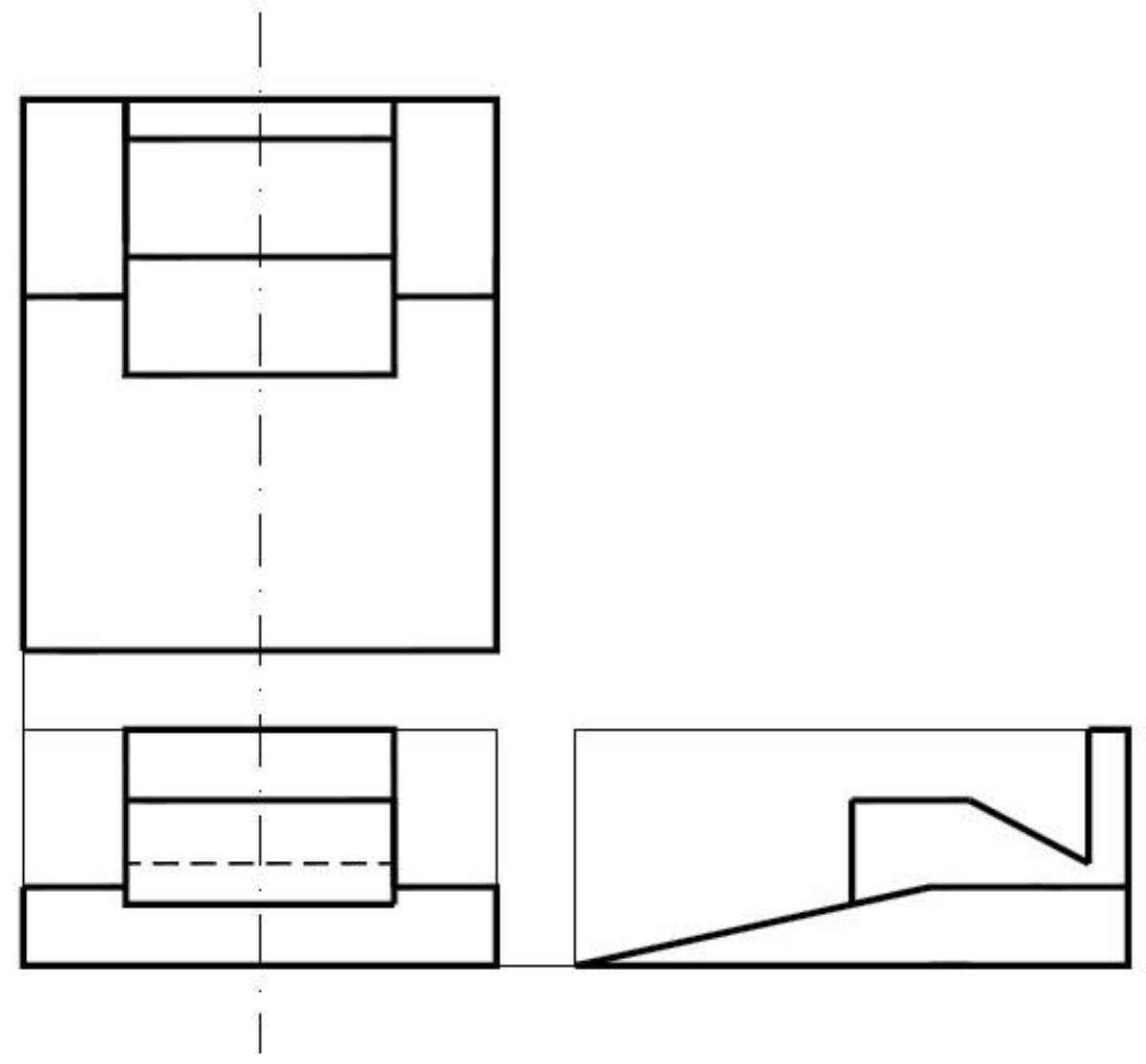

A solução dada por um aluno:
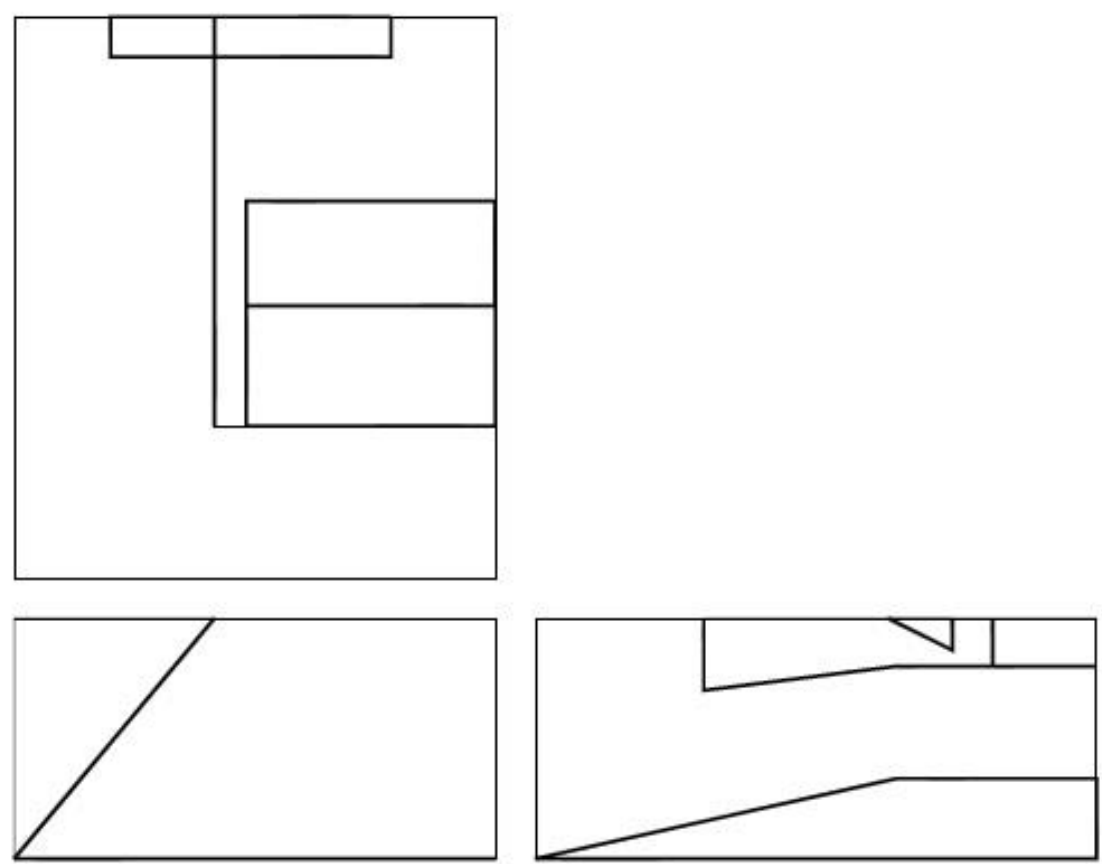
Solução esperada para o segundo exercício:
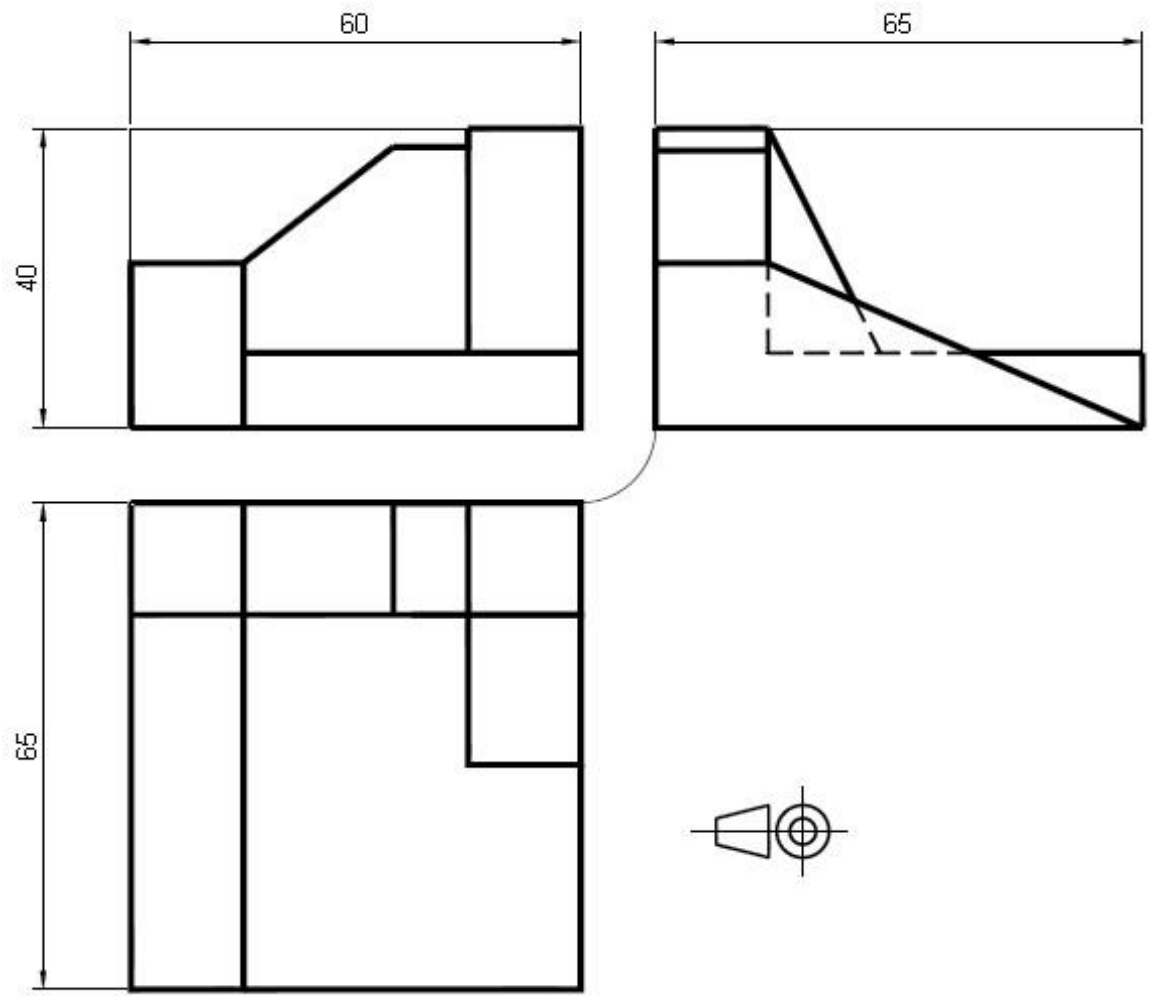

A solução dada por um aluno:
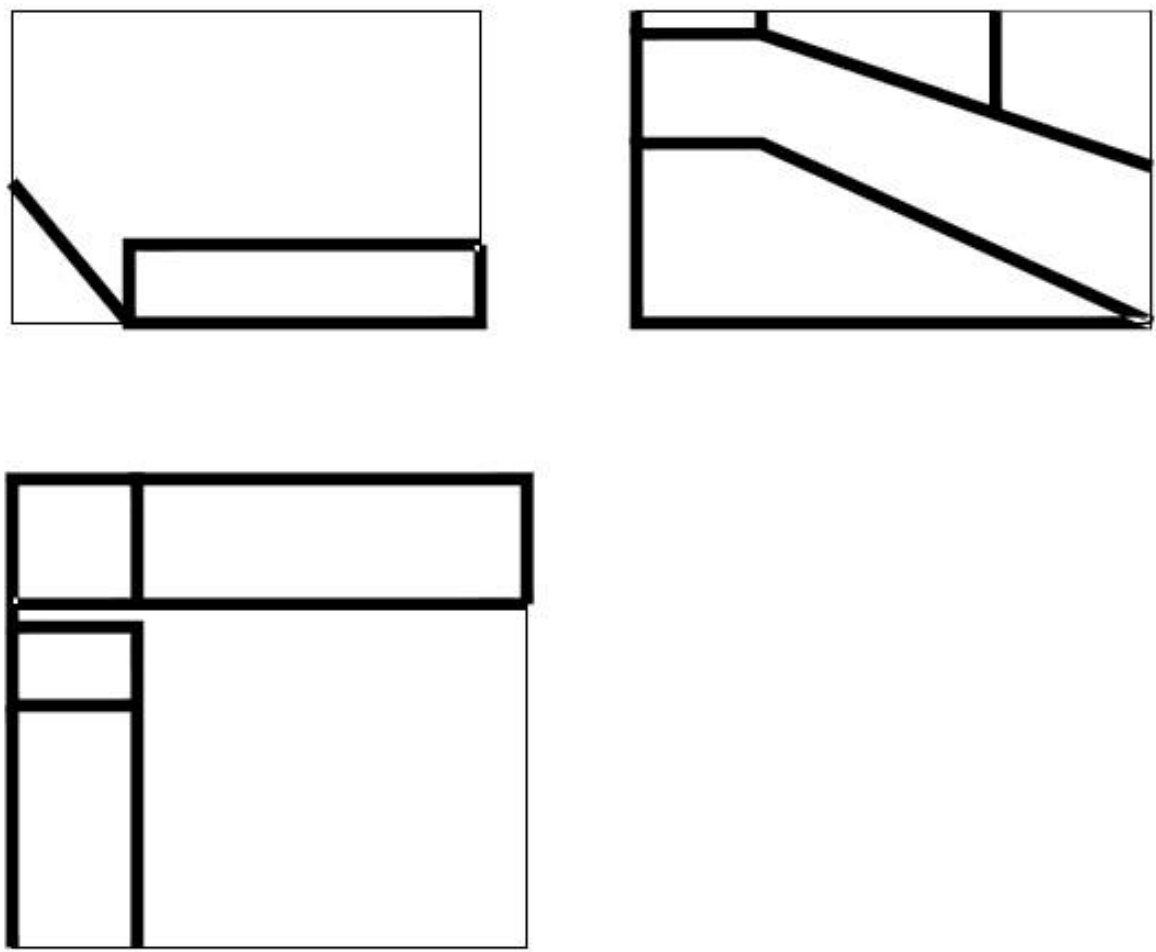
A construção da percepção visual se dá através da aparência externa de um objeto. A forma e a aparência servem para informar sobre a natureza das coisas. A diferença na aparência externa entre objetos indica sua finalidade. “...a diferença na aparência entre uma xícara de chá e uma faca indica qual objeto serve para conter líquido e qual para cortar um bolo." (ARNHEIM, R., 2004)

Quando uma peça de estudo é apresentada para o aluno, sua forma não está contida na coletânea de imagens coletadas ao longo de sua vida. Esse é o primeiro mecanismo usado para interpretação de um objeto ou peça colocada como exercício.

"Todas as vezes que a versão tridimensional de uma figura é suficientemente mais estável e simétrica do que a projeção plana, o observador tenderá a ver a sua configuração mais simples estendida em profundidade." (ARNHEIM, R., 2004)

O aluno recebe a imagem do objeto a partir da projeção retiniana tal como é visto fisicamente, porém, ao solicitar que desenhe o que a imagem do objeto, ele tende a desenhar a forma que mais se aproxima àquela coletada em sua memória visual.

Quando a figura é simples, como um hexaedro regular, o aluno associa facilmente a um cubo, usado regularmente em jogos de tabuleiro como "dado de tabuleiro", que é sabido, tem seis lados, cada lado numerado de um a seis com círculos opacos. Essa associação com um objeto real dá ao aluno plena interpretação do hexaedro quando desenhado em perspectiva ou em vistas ortográficas. Devido a esse "facilitador", o professor de desenho geralmente começa a construção de uma peça a partir de um sólido matriz ou de referência, contendo as mesmas dimensões do objeto que deseja reproduzir.
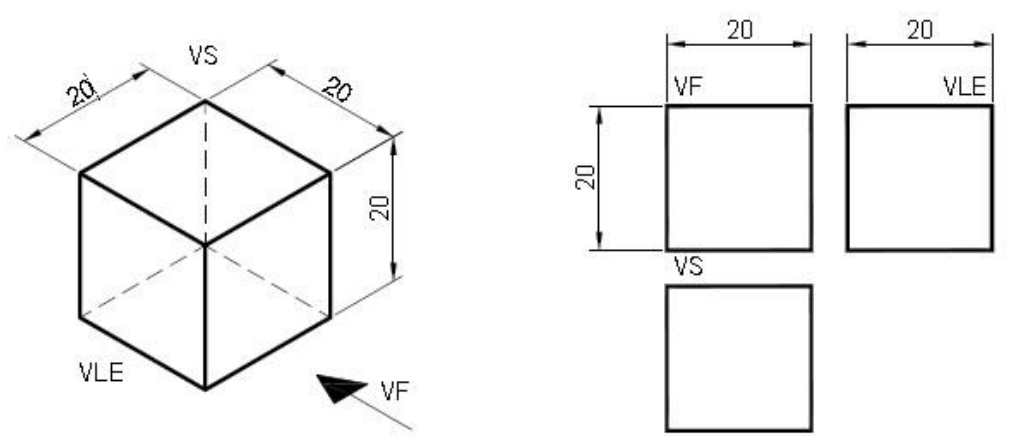
Mesmo que não sejam dadas as vistas ortográficas, o aluno tem condições de construir facilmente, em sua mente, as Vistas Ortográficas do hexaedro dado em perspectiva.

Efetuaremos uma pequena modificação no hexaedro, um recorte será efetuado na peça, resultando em uma fenda como mostra a figura a seguir.

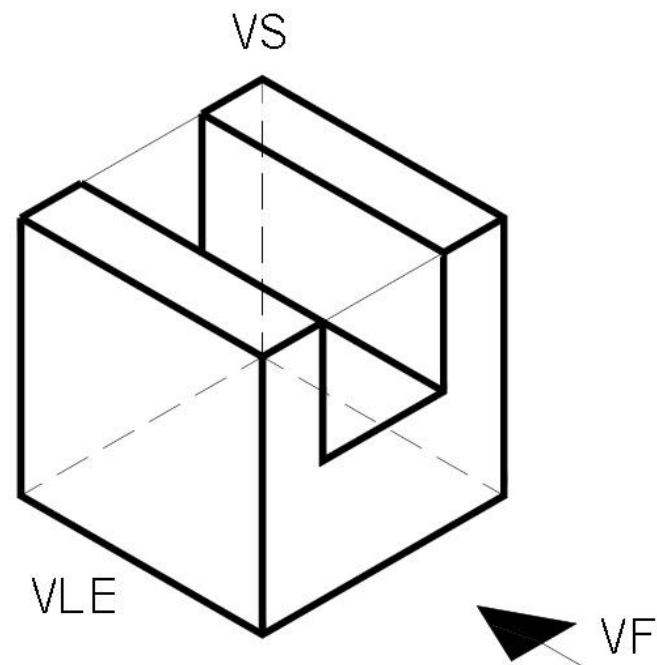

A partir da peça em perspectiva, temos as seguintes Vistas Ortográficas:

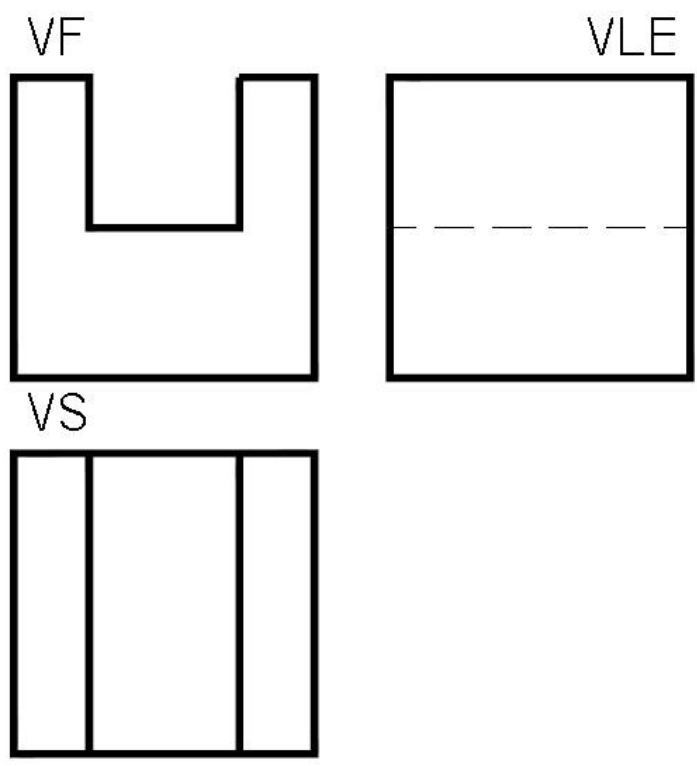

Até aqui o aluno não encontra muita dificuldade, pois mais uma faz associação da Vista Frontal com a letra "U" do alfabeto. 
Procederemos mais uma modificação na peça original, agora, aplicando uma rampa em um dos lados da peça em relação a Vista Frontal.

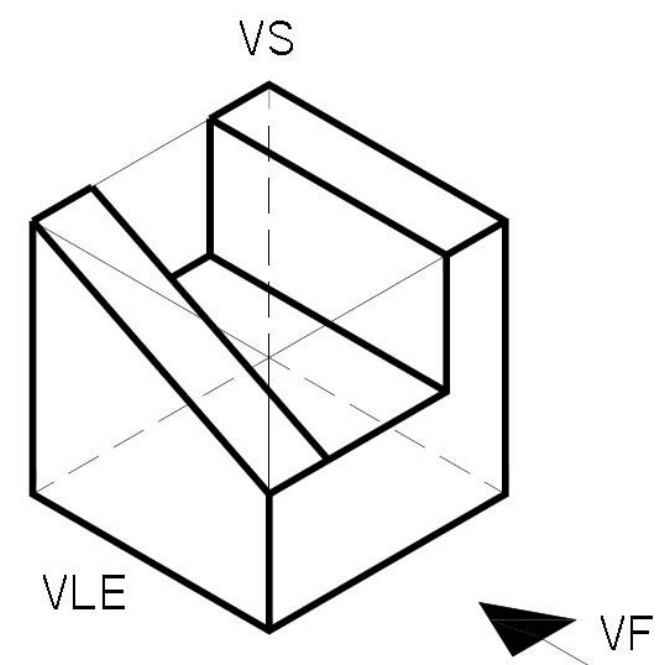

O resultado esperado da Vista Frontal é o que é mostrado na imagem abaixo.
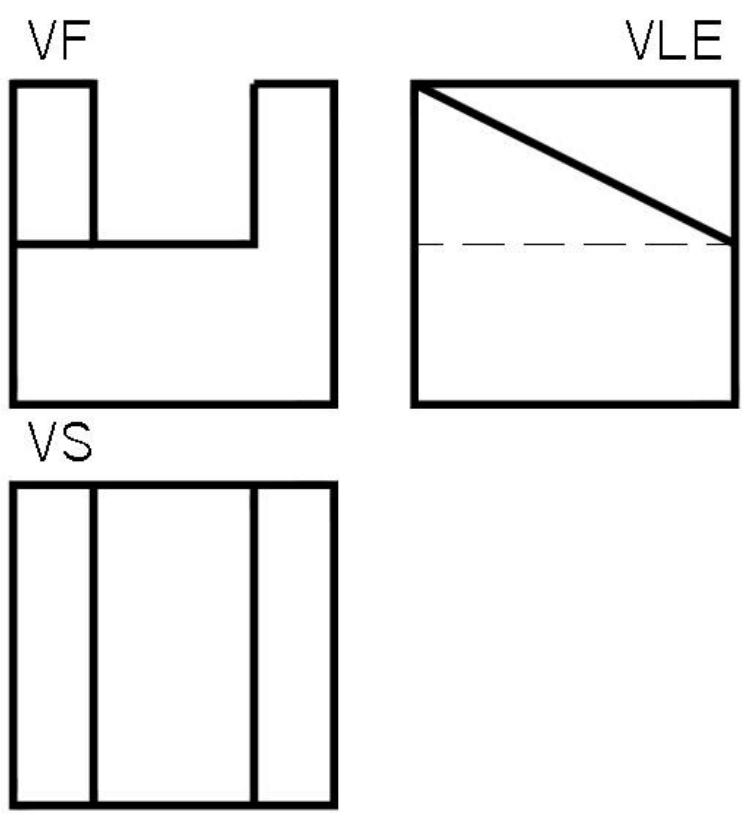

Desse ponto em diante começarão a aparecer as dificuldades, pois alguns alunos tentarão representar a rampa na Vista Frontal como veem na perspectiva, só que a rampa representa a hipotenusa de um triângulo retângulo e na Vista Frontal somente o cateto relacionado ao eixo das alturas é visto. 
Nesta figura abaixo, temos o triângulo retângulo referido anteriormente, de referência, assinalado em vermelho. A hipotenusa representa a rampa, e os catetos a altura e o comprimento.

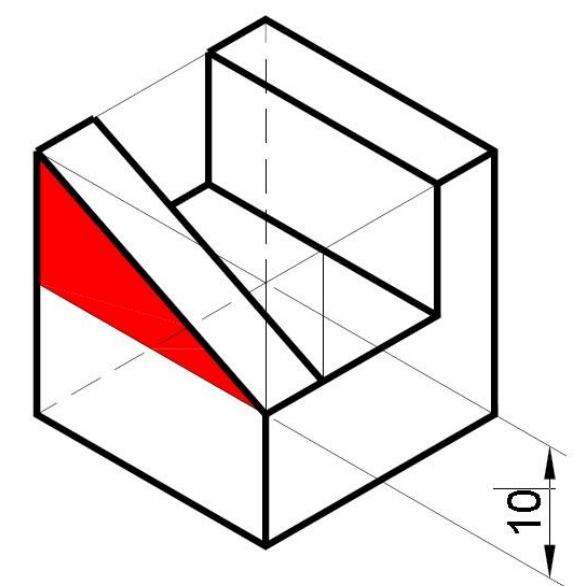

NOTA: na Vista Frontal são visíveis duas dimensões: largura e altura; na Vista Lateral o comprimento (ou profundidade) e altura; na Vista Superior comprimento e largura. 


\section{Sistema visual}

O sistema visual pode ser dividido em três partes principais:

- Olhos - funcionam como receptores do sistema visual, é a janela de entrada de toda imagem captada.

- Caminhos visuais - transportam e organizam a informação recebida.

- Córtex visual - é a parte do cérebro que gera a interpretação da imagem

\section{Olhos}

\section{Aspectos biológicos}

A parte ótica é constituída pela córnea, as lentes (cristalino) e a íris que, em conjunto, ajustam a intensidade e o foco da luz que entra. A retina, no fundo do olho e sensível à luz, é responsável por captar a luz e transformar em impulsos luminosos. Em síntese, o olho funciona como uma máquina fotográfica, ou seja, o conjunto de lentes capta a luz, ajusta a quantidade de luz e realiza o foco sobre o tecido óptico fotossensível.

O tecido óptico é constituído por dois tipos de células, os cones (cerca de 7 milhões de células) e bastonetes (cerca de 130 milhões de células). Os cones dependem da boa iluminação para serem eficientes, são responsáveis pela visão detalhada e pela percepção das cores, já os bastonetes provêm à percepção de contraste e movimento, atuam em baixa iluminação.

Os cones ficam mais concentrados em uma região denominada fóvea, onde quase inexistem os bastonetes, estes, se posicional em torno desta região em um ângulo de até 20 graus de excentricidade. Atingem a menor concentração, os cones e bastonetes a aproximadamente 80 graus de excentricidade. 
Quando é necessária focar um objeto ou cena, combinados são movimentos com os olhos e a cabeça de forma que a luz projetada atinja a região da fóvea, com isso o maior número de detalhes do objeto é obtido.

São fatores que influenciam a percepção visual:

- A iluminação

- Adaptação à intensidade da luz,

- Dispositivo de exibição da imagem,

- Interação com outros sentidos

Fatores individuais que influenciam a percepção visual:

- Idade

- Percepção de cor

- Visão estereoscópica

- Formações das lentes

- Estado emocional

- Experiência.

Vou detalhar dois itens, baseados nos estudos de PREECE (1994) e GRANDJEAN (1973), estado emocional e experiência.

"Estado emocional: O estado emocional do observador afeta a dilatação de sua pupila, consequentemente afetando a quantidade de luz que pode atingir sua retina." (Percepção Visual PUC-Rio).

Este item é interessante e explica, em parte, porque alunos que tem um bom desempenho em aula tem seu desempenho reduzido e até mesmo comprometido em momentos de stress quando são submetidos aos testes ou avaliações. Apesar 
das provas não terem peças com detalhes de difícil interpretação ou de complexidade muito acima das vistas em sala de aula, alguns alunos no momento de avaliação "travam".

"Experiência: A percepção de objetos pode ser influenciada por conhecimento prévio e experiências anteriores. " (Percepção Visual PUC-Rio).

Alunos que tiveram aulas de desenho para construção de objetos elementares, como hexaedros, poliedros simples ou pirâmides de base triangular ou quadrangular, tem facilidade para avançar no desenho de peças de complexidade maior, pois trazem a experiência e o conforto de "saber fazer". O esforço na interpretação de peças novas, e de maior complexidade, fica enormemente facilitado pela bagagem anterior. 


\section{Ações e possibilidades}

O professor de Desenho Técnico deve utilizar todos os recursos audiovisuais, disponíveis em sala de aula, para levar ao aluno o conteúdo da aula de Projeções Ortogonais. São as seguintes propostas de recursos:

- A começar pelos tradicionais desenhos no quadro, dessa forma incentivando o aluno a também desenhar à mão livre e buscar, da forma construtivista, o entendimento necessário para execução da tarefa.

- O uso do data-show com exposições das etapas de desenho das Projeções Ortogonais é um recurso bem interessante e esclarecedor. É recomendável que o professor interaja com as imagens projetadas desenhando com canetas Pilot sobre as projeções, conseguindo assim um efeito de "animação".

- Exposição por meio do data-show e desenhos com as etapas de construção das Vistas Ortográficas usando os recursos de animação do Power Point.

- Peças físicas, modelos em MDF com as formas exatas das usadas nas projeções e desenho.

- Outro jogo de peças físicas em acrílico, com as mesmas dimensões das feitas em MDF, onde as arestas seriam em acrílico opaco e um ponto emissor de luz "plana" (projetor de transparências).

- Apresentação em Power Point contendo o conteúdo da aula de Projeções Ortogonais.

- Vídeo aula sobre Projeções Ortogonais contendo o conteúdo da aula. 


\section{Conclusão}

É consenso, entre os professores de desenho, que a Geometria Descritiva (GD) deveria ser pré-requisito para o aluno de Desenho Técnico. $\mathrm{O}$ estudo do ponto e da reta no espaço mongeano, com o mapeamento dos pontos em relação aos eixos $\mathrm{X}, \mathrm{Y}$ e $\mathrm{Z}$ e as diversas posições relativas das retas e suas respectivas projeções nos planos $\pi, \pi$ ' e $\pi$ ' é fundamental para a interpretação de um objeto, suas respectivas arestas, vértices e planos constituintes.

A falta do conteúdo da GD (Geometria Descritiva) aparece em questões elementares nos exercícios de projeção das vistas ortográficas. Alguns alunos, por suas características particulares ou por trazer bagagem técnica proveniente de cursos de desenho, saem-se bem nas aulas de Desenho Técnico, outros necessitariam de obter mais elementos para construir a visão espacial necessária para executar os exercícios, e obter o conhecimento esperado na disciplina.

Cabe ao professor ter a necessária sensibilidade em identificar o aluno citado no segundo caso e dar a ele apoio fazendo uso dos recursos didático-tecnológicos à disposição. 


\section{Referências Bibliográficas}

ARNHEIM, R. Arte \& Percepção Visual Uma Psicologia da Visão Criadora. São Paulo, SP: Thomson, 2004.

FRENCH, T.E.; VIERCK, C.J. Desenho Técnico e Tecnologia Gráfica. São Paulo, SP: Editora Globo S.A., 1985

HOELSCHER, R.P.; SPRINGER, C.H.; DOBROVOLNY, J.S. Expressão Gráfica de Desenho Técnico. Rio de Janeiro, RJ: Livros Técnicos e Científicos Editora S.A., 1978.

PINHEIRO, V.A. Noções de Geometria Descritiva. Rio de Janeiro, RJ: Ao Livro Técnico S.A., 1961.

RABELLO, P.S.B. Geometria Descritiva Básica I. Cabo Frio, RJ. 2005.

Percepção Visual, PUC-Rio Certificação Digital nº 0610421/CA em: http://www.maxwell.vrac.puc-rio.br/12044/12044_4.PD 
